\title{
Transcriptomic Profiling of Equine and Viral Genes in Peripheral Blood Mononuclear Cells in Horses during Equine Herpesvirus 1 Infection
}

\author{
Lila M. Zarski ${ }^{1}$, Patty Sue D. Weber ${ }^{2}$, Yao Lee ${ }^{1}$ and Gisela Soboll Hussey ${ }^{1, * \mathbb{D}}$ \\ 1 Department of Pathobiology and Diagnostic Investigation, Michigan State University, East Lansing, \\ MI 48824, USA; zarskili@msu.edu (L.M.Z.); windy77919@gmail.com (Y.L.) \\ 2 Department of Large Animal Clinical Sciences, Michigan State University, East Lansing, MI 48824, USA; \\ weberp@msu.edu \\ * Correspondence: husseygi@msu.edu
}

Citation: Zarski, L.M.; Weber, P.S.D.; Lee, Y.; Soboll Hussey, G.

Transcriptomic Profiling of Equine and Viral Genes in Peripheral Blood Mononuclear Cells in Horses during Equine Herpesvirus 1 Infection. Pathogens 2021, 10, 43. https:// doi.org/10.3390/pathogens10010043

Received: 12 December 2020

Accepted: 5 January 2021

Published: 7 January 2021

Publisher's Note: MDPI stays neutral with regard to jurisdictional clai$\mathrm{ms}$ in published maps and institutional affiliations.

Copyright: (C) 2021 by the authors. Licensee MDPI, Basel, Switzerland. This article is an open access article distributed under the terms and conditions of the Creative Commons Attribution (CC BY) license (https:// creativecommons.org/licenses/by/ $4.0 /)$.

\begin{abstract}
Equine herpesvirus 1 (EHV-1) affects horses worldwide and causes respiratory disease, abortions, and equine herpesvirus myeloencephalopathy (EHM). Following infection, a cellassociated viremia is established in the peripheral blood mononuclear cells (PBMCs). This viremia is essential for transport of EHV-1 to secondary infection sites where subsequent immunopathology results in diseases such as abortion or EHM. Because of the central role of PBMCs in EHV-1 pathogenesis, our goal was to establish a gene expression analysis of host and equine herpesvirus genes during EHV-1 viremia using RNA sequencing. When comparing transcriptomes of PBMCs during peak viremia to those prior to EHV-1 infection, we found 51 differentially expressed equine genes (48 upregulated and 3 downregulated). After gene ontology analysis, processes such as the interferon defense response, response to chemokines, the complement protein activation cascade, cell adhesion, and coagulation were overrepresented during viremia. Additionally, transcripts for EHV-1, EHV-2, and EHV-5 were identified in pre- and post-EHV-1-infection samples. Looking at micro RNAs (miRNAs), 278 known equine miRNAs and 855 potentially novel equine miRNAs were identified in addition to 57 and 41 potentially novel miRNAs that mapped to the EHV-2 and EHV-5 genomes, respectively. Of those, 1 EHV-5 and 4 equine miRNAs were differentially expressed in PBMCs during viremia. In conclusion, this work expands our current knowledge about the role of PBMCs during EHV-1 viremia and will inform the focus on future experiments to identify host and viral factors that contribute to clinical EHM.
\end{abstract}

Keywords: EHV-1; herpesvirus; horse; PBMC; transcriptomics; RNA sequencing; microRNA; gene expression

\section{Introduction}

Herpesviridae are ubiquitous pathogens that infect most mammals, birds, and reptiles. They are enveloped, double-stranded DNA viruses with the trademark ability to establish life-long latency in their hosts. The latent genome packages itself within the cell nucleus as a circular extra-chromosomal episome of viral genomic DNA [1]. Latent infections are typically subclinical, though reactivation or reinfection from another host can produce active clinical disease. In horses, the most commonly described herpesviruses include Equid alphaherpesvirus 1 (EHV-1), Equid gammaherpesvirus 2 (EHV-2), Equid alphaherpesvirus 4 (EHV-4), and Equid gammaherpesvirus 5 (EHV-5) [2]. These viruses fall into two main subfamilies: Alphaherpesvirinae (EHV-1 and EHV-4) and Gammaherpesvirinae (EHV-2 and EHV-5). Alphaherpesviruses are known for their rapid lytic replication in many cell types [2]. Alphaherpesviruses typically (though not exclusively) establish latency in the sensory ganglia of their host; however, EHV-1 is also known to establish latency in lymphoid tissues [3-7]. On the other hand, gammaherpesviruses are more restrictive in 
their cell tropism and are known to establish latency primarily in lymphocytes as well as for their slow replication cycle $[1,8]$.

In horses, alpha- and gammaherpesviruses are ubiquitous and have been reported to be detected in their respective tissues of latency in over $75 \%$ of healthy animals $[2,4,8]$. For equine gammaherpesviruses, the role of infection in clinical disease is not well understood. However there are reports showing an association with pulmonary fibrosis, pharyngitis, dermatitis, lymphoma, and other conditions [8]. In contrast, active infections with the equine alphaherpesviruses EHV-1 and EHV-4 are primary causes of acute respiratory disease in younger animals, which is a major contributor to loss of training [9]. In addition, EHV-1 also can cause late-term abortion, neonatal death, ocular disease, or the neurologic disease equine herpesvirus myeloencephalopathy (EHM) in up to $10 \%$ of infected cases [9]. This is in contrast to EHV-4 infection, which typically stays restricted to the respiratory tract and does not cause abortions or EHM [10].

The key reason for the difference in secondary clinical disease manifestations between EHV-1 and EHV-4 is the fact that EHV-1 establishes viremia, which is essential for transporting the virus from the respiratory tract to the secondary sites of infection. In contrast, viremia is not known to be a central feature of EHV-4 disease pathogenesis. EHV-1 establishes viremia in peripheral blood mononuclear cells (PBMCs) shortly after initial infection of the respiratory epithelium. Within the population of PBMCs, monocytes, $\mathrm{T}$ cells, and B cells have been shown to become infected with EHV-1, and there are conflicting reports on which of these subpopulations the virus prefers [11-15]. Unlike the lytic life cycle of infected epithelial cells in which full transcription and replication of virions destroys cells and produces free virus, infection in PBMCs is characterized by a restricted viral gene expression, which delays viral replication until the cell has made contact with the vascular endothelium [16-18]. This allows the virus to effectively evade immune surveillance within the PBMCs while being transported to the secondary sites of infection. Furthermore, it is likely that viremia is an important step in the establishment of latency of EHV-1 in lymphoid tissues [7].

Thus, the period of viremia is a critical prerequisite for the development of secondary diseases such as EHM and abortions. It has been shown that EHM generally develops during the end of viremia and that a longer duration and higher magnitude of viremia contribute to the likelihood of EHM [19]. It is presumed that the prolonged exposure to infected PBMCs increases the potential of viral transfer to the vascular endothelium. In addition to the necessity of viral transfer to the vascular endothelium, perhaps the most critical factor affecting vascular damage and, subsequently, the clinical outcome is the immunopathology that occurs at this site. Because PBMCs are a robust immune and inflammatory cell population in the vasculature, as well as carriers of EHV-1 virus, they are an important focus of investigation of EHV-1-associated secondary diseases.

Despite the importance of PBMCs for the development of secondary EHV-1-associated diseases, limited information is available about the host or viral gene expression in these cells during this period. At this point, various cytokines such as interleukin-10, interferon gamma (IFN $\gamma$ ), and tumor necrosis factor beta have been shown to be induced in the blood of horses during EHV-1 viremia [20,21]. In vitro, EHV-1 induces expression of interferons, cytokines, and chemokines in both epithelial cells and PBMCs [22,23]. However, a complete profile of host and viral messenger RNA (mRNA) expression has not yet been performed.

In addition, micro RNAs (miRNAs) may play a role in the regulation of host and viral gene expression in PBMCs during viremia. MiRNAs are small ( 22 bases) RNA molecules that block the translation of their target coding mRNAs [24]. It is becoming clear that host and viral miRNAs play an important role in the evasion of immune detection as a response to EHV-1 infection. Cellular (host) miRNAs have been shown to inhibit viral genome replication for herpes simplex virus 1 (HSV-1), which likely contributes to the virus' ability to persist in the cell undetected [25]. Virally encoded miRNAs have been identified in several herpesviruses and play an important role in viral persistence in cells by 
downregulating host immune responses [26]. Currently, the role of miRNAs is unknown for EHV-1 replication.

The goal of this study was to use RNA sequencing to analyze the mRNA and miRNA transcriptome of equine PBMCs before and during EHV-1 viremia as an unbiased and comprehensive approach to gene expression analysis. Our rationale was that this approach can be used to reveal mechanisms involved in infection of the vascular endothelium and facilitate understanding of the events that contribute to EHV-1 secondary disease. This information is essential to aid in the development of prophylactics or treatments against secondary EHV-1 diseases and will inform the focus on future experiments to identify host and viral factors that contribute to EHM and abortions.

\section{Results}

\subsection{Clinical Disease and Viremia}

All horses were free from clinical signs of respiratory disease and had normal body temperatures prior to infection with EHV-1. As described previously, all horses developed fevers, shed virus in nasal secretions, and seroconverted following EHV-1 inoculation, indicating successful challenge infection (Figure 1A,C) [27]. As expected, viral DNA was more prominent in nasal secretions than in PBMCs. One horse (horse 6) developed severe EHM and was euthanized day 11 post-challenge. PBMC samples were analyzed for viremia for 10 days following challenge by quantitative real-time PCR (qPCR). The day of peak viremia was identified for each horse and occurred between days 5 and 8 post-infection (p.i.) (Figure 1B) [27].
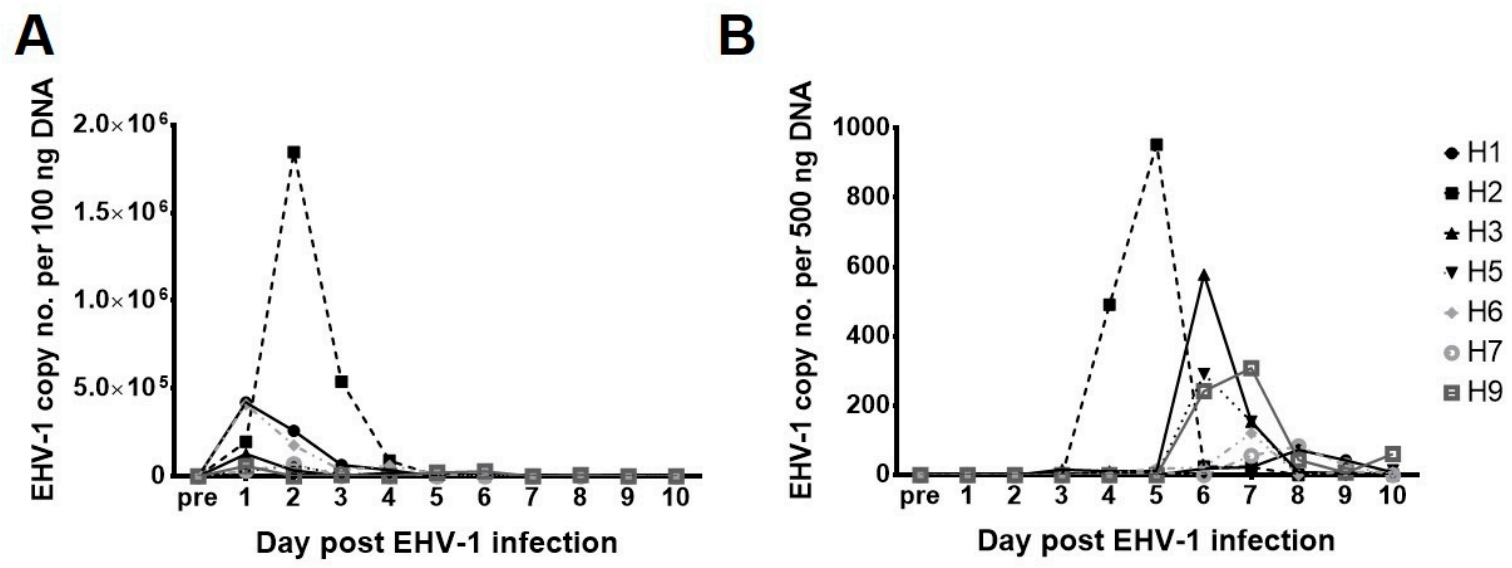

\section{C}

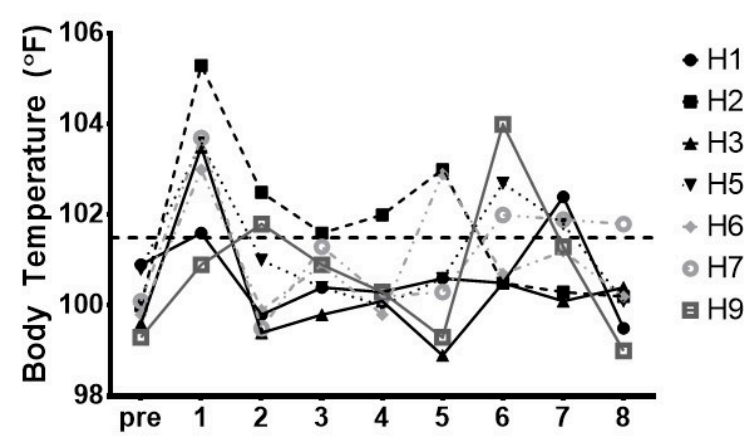

Day post EHV-1 infection

Figure 1. Clinical and virological disease post equine herpesvirus 1 (EHV-1) challenge. (A) EHV-1 nasal shedding. Data are expressed as EHV-1 copy number per $100 \mathrm{ng}$ template DNA as determined by qPCR. (B) Viremia. Data are expressed as EHV-1 copy number per $500 \mathrm{ng}$ template DNA as determined by qPCR. (C) Body temperature. A body temperature over $101.5^{\circ} \mathrm{F}$ was considered as a fever and is indicated by the horizontal dashed line. 


\subsection{Horse mRNA Sequencing and Differential Gene Expression}

The mapping summary statistics is shown in Table 1 and describe the number of total reads and uniquely mapped reads. The read depth was 43,480,084 total reads on average per sample, and an average of $80.3 \%$ of reads uniquely mapped to the equine genome.

Table 1. Mapping summary statistics of mRNA sequencing.

\begin{tabular}{cccc}
\hline Sample ID & Total Reads & Uniquely Mapped (Number of Reads) & Uniquely Mapped (\%) \\
\hline H1_PRE & $26,999,513$ & $21,296,243$ & 78.9 \\
\hline H1_POST & $27,536,037$ & $20,976,540$ & 76.2 \\
\hline H2_PRE & $35,256,030$ & $29,155,433$ & 82.7 \\
\hline H2_POST & $42,517,852$ & $33,582,323$ & 79.0 \\
\hline H3_PRE & $56,397,724$ & $45,505,043$ & 80.7 \\
\hline H3_POST & $63,282,694$ & $51,758,322$ & 81.8 \\
\hline H5_PRE & $93,180,427$ & $75,568,952$ & 81.1 \\
\hline H5_POST & $27,862,507$ & 83.7 \\
\hline H6_PRE & $50,453,360$ & 81.0 \\
\hline H6_POST & $24,740,083$ & $40,889,209$ & 77.1 \\
\hline H7_PRE & $26,710,306$ & $19,062,322$ & 78.3 \\
\hline H7_POST & $52,898,636$ & $20,926,895$ & 81.5 \\
\hline H9_PRE & $51,887,615$ & $43,121,055$ & 82.3 \\
\hline H9_POST & $28,998,398$ & $42,716,415$ & 79.9 \\
\hline Average & $43,480,084$ & $23,182,557$ & 80.3 \\
\hline
\end{tabular}

Mapping summary statistics of mRNA sequencing. Total reads after sequencing and the number and percent that uniquely mapped to the EquCab3.0 genome are shown for each sample.

The principal component analysis (PCA) of regularized log-transformed read-count data shows a clustering of samples based on timepoint (pre-infection vs. post-infection) (Figure 2A). When comparing pre-infection with post-infection samples, we found a total of 3226 differentially expressed genes (DEGs) with an adjusted $p$ value (padj) $<0.05$ (File S1). Due to the high number of DEGs and in order to highlight the most relevant biological processes in downstream enrichment analyses, we set the significance threshold at padj $<0.05$ and $\log 2$ fold change greater than 3 or less than -3 . At this threshold, there were 51 DEGs, 48 of which were significantly upregulated and 3 genes that were significantly downregulated (Figure 2B).

Functional information for available genes from the Homo sapiens uniprotKB database revealed numerous genes involved in various aspects of inflammation. The majority of upregulated genes belonged to the interferon pathway (such as DDX60, MX2, MX1, GBP2, IFIT3, IFI44, OAS1, OASL, OAS3, TRIM22, OAS2, IFIT5, IFI6, and IRF7). In addition, many chemotactic genes (CXCL9, CXCL10, CXCL11, and CCL8) as well as genes involved in the complement system (C1R, C3AR1, and SERPING1) were upregulated, as well as other genes which are shown in Table A1. The three downregulated genes included fibronectin (FN1), which encodes an adhesion molecule, as well as DEFB1, the gene that encodes the antimicrobial protein beta defensin 1 , and the gene FAM71A. 


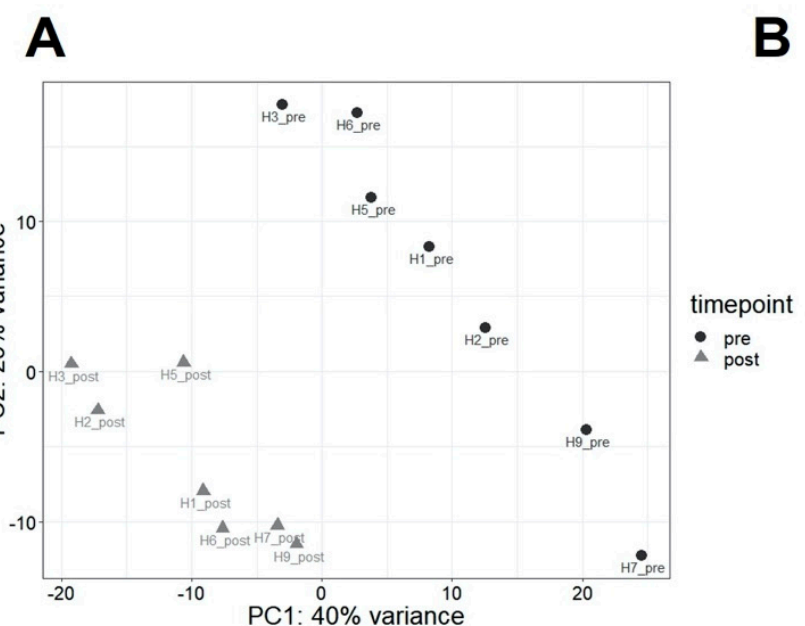

B

Figure 2. (A) Principal component analysis. Samples from horses pre-infection (black dots) cluster separately from samples during viremia (gray triangles). The horse numbers are indicated on the plot as $\mathrm{H} 1-\mathrm{H} 9$, and $\mathrm{H} 3$ and $\mathrm{H} 5$ were females. (B) Differentially expressed genes in horses pre-infection vs. post-infection. Genes with positive log2 fold change (x-axis) indicate genes upregulated in peripheral blood mononuclear cells (PBMCs) during EHV-1 infection compared to preinfection while negative log2 fold change values indicate genes downregulated in PBMCs during infection. p-values are expressed on the y-axis, with more significantly differentially expressed genes towards the top of the plot. Genes highlighted in red passed the threshold of significance set at adjusted $p$-value $<0.05$ and log2 fold change $>|3|$.

\subsection{Gene Ontology (GO) Overrepresentation}

Due to the low number of downregulated genes, the gene ontology (GO) overrepresentation analysis focused on processes involved in the upregulated gene list. The gene ontology overrepresentation analysis was performed on the 48 upregulated genes and 150 total GO terms for biological processes were enriched (File S2). After summarizing the list with a tool that summarizes lists of GO terms based on semantic similarity (REVIGO), 18 non-redundant enriched GO terms remained (Figure 3A). The most significantly enriched process was defense response to virus (GO:0051607), which also included the most genes (16) from our gene list. The other top significantly enriched processes were negative regulation of viral genome replication (GO:0045071), regulation of nuclease activity (GO:0043950), positive regulation of cyclic adenosine monophosphate (cAMP)-mediated signaling (GO:0043950), and cellular response to chemokines (GO:1990869).

Genes associated with the top nine most significantly enriched GO terms are visualized in Figure 3B. These genes and processes cluster into three general groups. The largest group contains genes and processes involved in the defense response to viruses, negative regulation of viral genome replication, and regulation of nuclease activity and includes DDX60, MX2, MX1, GBP2, IFIT3, IFI44, OAS1, OASL, OAS3, TRIM22, OAS2, IFIT5, IFI6, and IRF7. The genes for chemokines CCL8, CXCL9, CXCL10, and CXCL11 are involved with a second cluster of biological processes including cellular response to chemokines, positive regelation of cAMP-mediated signaling, and positive regulation of release of sequestered calcium ion into cytosol. The third main cluster includes three genes associated with the complement system, C1R, SERPING1, and C3AR1, which are involved with the enriched terms regulation of protein activation cascade, protein activation cascade, and regulation of protein maturation. 


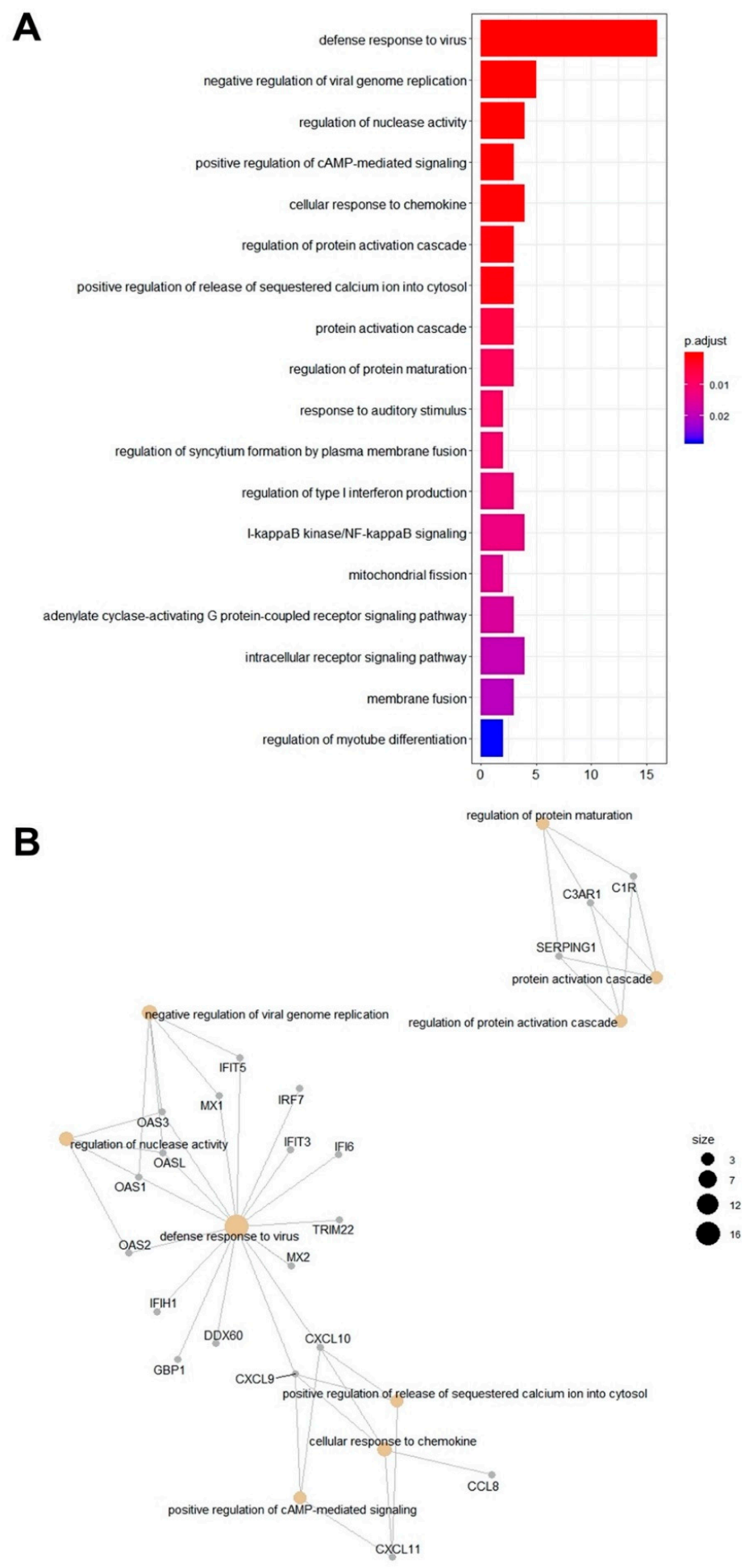

Figure 3. (A) Gene ontology (GO) terms for biological processes overrepresented in horses during EHV-1 infection. GO term enrichment analysis was performed using the enrichgo function of the clusterprofiler package in R. The resulting terms were filtered for redundancy using REVIGO. The 18 non-redundant enriched GO terms are visualized here. The most significantly enriched terms are at the top and are listed in decreasing significance (increasing padj). The number of genes from our gene list are indicated on the x-axis. (B) Net plot of the most significantly enriched GO terms and associated genes. The ten non-redundant GO terms with the lowest padj values are listed here with the associated genes from our gene list. Tan nodes represent the GO term and gray nodes represent genes. The size of the GO term nodes indicates the number of genes from our list associated with that term. The biological processes and the associated genes cluster based on similarity. 


\subsection{In Silico Cell Sorting}

Average cell fractions between pre- and post-infection samples and the averages \pm SEM for each cell type are shown in Table 2. Following challenge infection during peak viremia, there was a significant increase in $\gamma \delta \mathrm{T}$ cells $(p<0.05)$ and M1 polarized macrophages $(p<0.1)$. Additionally, there was a significant reduction in CD8+ T cells $(p<0.05)$, plasma cells $(p<0.1)$, and M0 macrophages $(p<0.1)$ post-infection.

Table 2. Average fraction of cell populations.

\begin{tabular}{|c|c|c|}
\hline & $\begin{array}{c}\text { Pre-Challenge (\% of Total Cell } \\
\text { Population) }\end{array}$ & $\begin{array}{l}\text { Post-Challenge (\% of Total Cell } \\
\text { Population) }\end{array}$ \\
\hline$B$ cells naive & $42.07 \pm 0.02$ & $39.89 \pm 0.01$ \\
\hline B cells memory & $0.00 \pm 0.00$ & $0.62 \pm 0.01$ \\
\hline Plasma cells & $0.38 \pm 0.00$ & $0.00 \pm 0.00 *$ \\
\hline T cells CD8 & $2.37 \pm 0.00$ & $0.46 \pm 0.00 * *$ \\
\hline $\mathrm{T}$ cells CD4 naive & $5.52 \pm 0.02$ & $6.95 \pm 0.02$ \\
\hline $\mathrm{T}$ cells CD4 memory resting & $1.34 \pm 0.01$ & $1.04 \pm 0.01$ \\
\hline $\mathrm{T}$ cells CD4 memory activated & $5.55 \pm 0.01$ & $3.28 \pm 0.01$ \\
\hline T cells follicular helper & $17.75 \pm 0.02$ & $16.69 \pm 0.01$ \\
\hline $\mathrm{T}$ cells regulatory (Tregs) & $0.88 \pm 0.00$ & $1.05 \pm 0.01$ \\
\hline T cells gamma delta & $1.11 \pm 0.00$ & $4.00 \pm 0.00 * *$ \\
\hline Natural killer cells resting & $2.32 \pm 0.01$ & $1.32 \pm 0.01$ \\
\hline Natural killer cells activated & $0.18 \pm 0.00$ & $0.51 \pm 0.00$ \\
\hline Monocytes & $4.38 \pm 0.01$ & $4.71 \pm 0.01$ \\
\hline Macrophages M0 & $1.49 \pm 0.00$ & $0.00 \pm 0.00 *$ \\
\hline Macrophages M1 & $0.00 \pm 0.00$ & $2.14 \pm 0.01 *$ \\
\hline Macrophages M2 & $2.39 \pm 0.00$ & $3.18 \pm 0.00$ \\
\hline Dendritic cells resting & $0.00 \pm 0.00$ & $0.66 \pm 0.00$ \\
\hline Dendritic cells activated & $4.98 \pm 0.00$ & $5.84 \pm 0.01$ \\
\hline Mast cells resting & $0.00 \pm 0.00$ & $0.64 \pm 0.01$ \\
\hline Mast cells activated & $2.89 \pm 0.01$ & $1.54 \pm 0.01$ \\
\hline Eosinophils & $4.22 \pm 0.01$ & $4.92 \pm 0.01$ \\
\hline Neutrophils & $0.15 \pm 0.00$ & $0.55 \pm 0.00$ \\
\hline
\end{tabular}

The average fraction of cell population fractions for each sample was estimated using CIBERSORTx [28] and the reference gene signature "LM22" included with the software, which is based off of the transcriptome of human PBMC samples with pre-determined cell populations. Wilcoxon's signed-rank test was performed. * indicates $p \leq 0.1$ and ${ }^{* *}$ indicates $p \leq 0.05$.

Relative cell percentages for 22 different leukocyte subpopulations in individual horses pre-and post-infection can be seen in Figure 4. Overall, the most abundant cell type identified in all samples was naïve B cells, with around $40 \%$ of the estimated cell fraction, followed by follicular T helper cells with $\sim 17 \%$. Interestingly, horse \#6, who was the only horse exhibiting clinical EHM, was also the only horse showing an increase in naïve B cells and $\mathrm{T}$ follicular helper cells and one of two horses exhibiting visible increases in the percentage of $\mathrm{T}$ regulatory cells. 


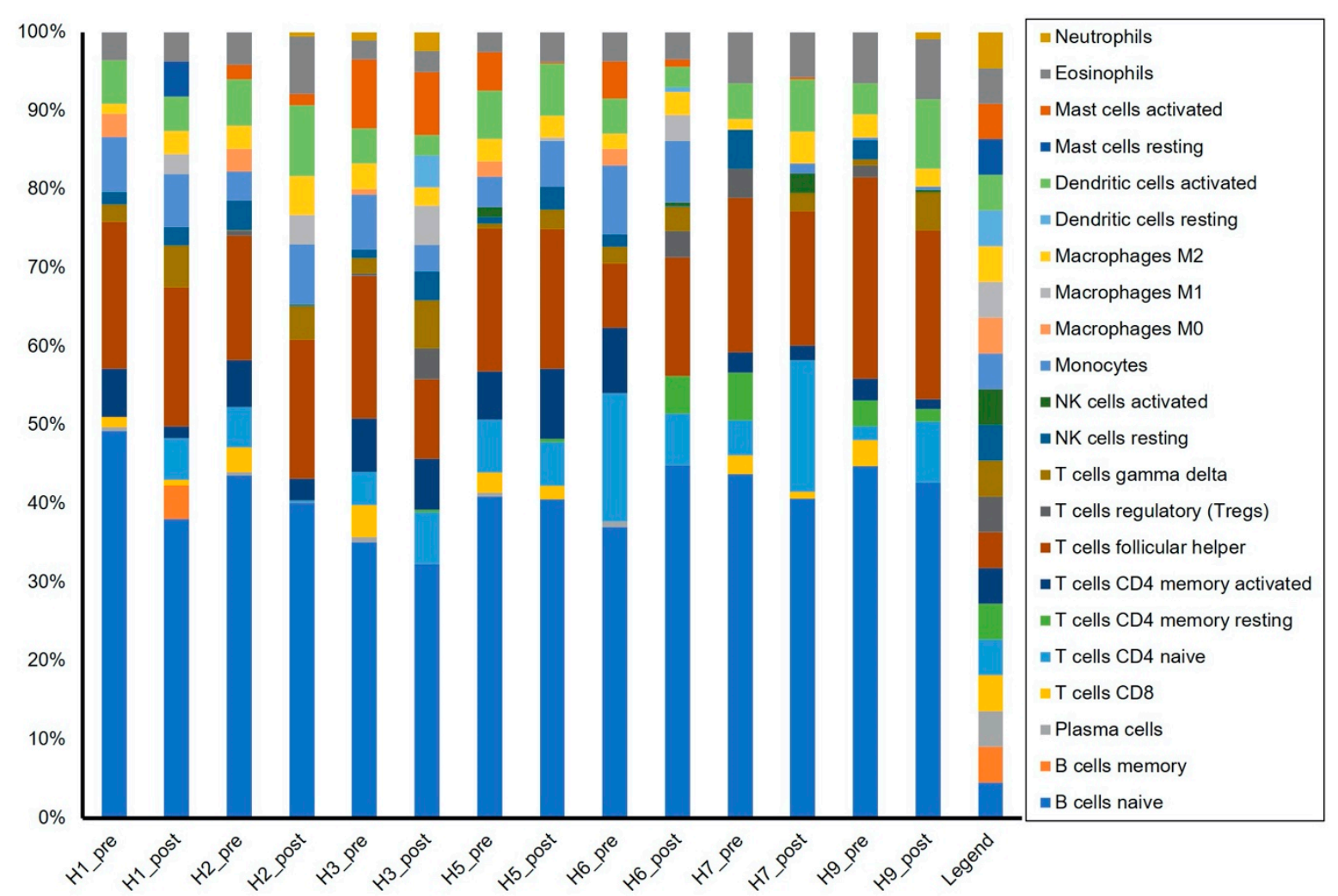

Figure 4. Cell population fractions in PBMC samples. Cell population fractions for each sample were estimated using CIBERSORTx and the reference gene signature "LM22" included with the software, which is based on the transcriptome of human PBMC samples with pre-determined cell populations. Twenty-two cell subpopulations are represented by different colors. Fractions are expressed as percent of the total population (y-axis) for each sample (x-axis).

\subsection{Viral mRNA Sequencing}

Normalized read counts in transcripts per million (TPM) for EHV-1, EHV-2, and EHV-5 were identified and are shown in File S3. No reads mapped to the EHV-4 genome. Read coverage along the EHV-1 genome shows a low level of transcription of viral reads in 5/7 of the horses prior to EHV-1 challenge (Figure 5). As expected, during EHV-1 viremia post-challenge, read coverage of the EHV-1 genome increased and EHV-1 transcripts were present in all samples (Figure 5). Additionally, the horses with the highest levels of viremia corresponded to the samples with the most EHV-1 transcription post-challenge (Figure 1B; Figure 5). TPM values for each gene were then averaged and the most abundant EHV-1 genes expressed post-infection were ORF25, ORF34, and ORF75 (Figure 6A). The products of these genes include a capsid protein (ORF25) and a protein involved in the early step of virus egress (ORF34). ORF75 encodes a membrane protein presumed to be involved in the virulence of certain EHV-1 strains [29,30]. The most abundant EHV-1 genes pre-infection were ORF59, ORF25, and ORF58 (Figure 6A). ORF59 encodes an early protein involved in viral growth and ORF58 encodes a nuclear non-structural protein [30,31]. Interestingly, three genes, namely ORF59, ORF41 (encodes a membrane protein), and ORF55 (encodes a tegument protein), had higher levels of transcription in pre-infection PBMCs compared to PBMCs during viremia. This could indicate a role for these genes in EHV-1 persistence in PBMCs during clinical latency. 

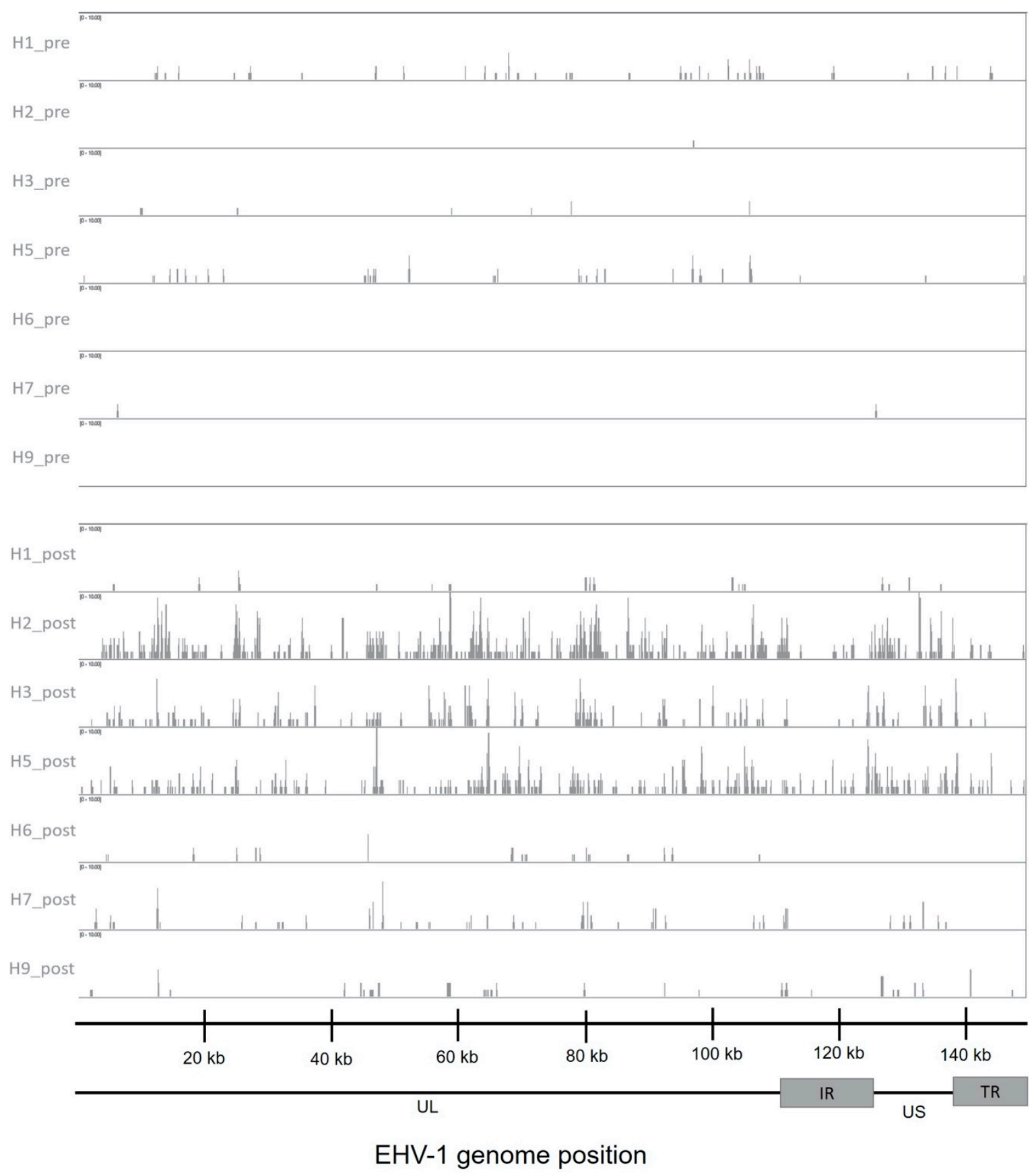

Figure 5. Read coverage plot of the EHV-1 genome. The top seven tracks are the pre-infection samples, and the bottom seven tracks are post-infection samples. Reads were aligned to the EHV-1 strain Ab4 genome (NCBI RefSeq NC_001491.2). $\mathrm{UL}=$ unique long region; $\mathrm{IR}=$ internal repeat region; $\mathrm{US}=$ unique small region; $\mathrm{TR}=$ terminal repeat region, as described in [30].

Additionally, transcription of the equine gammaherpesvirus (EHV-2 and EHV-5) genes was present in PBMCs prior to and after EHV-1 challenge (Figure 6B,C). No apparent differences were observed in TPM of EHV-2 or EHV-5 genes in response to EHV-1 infection. 

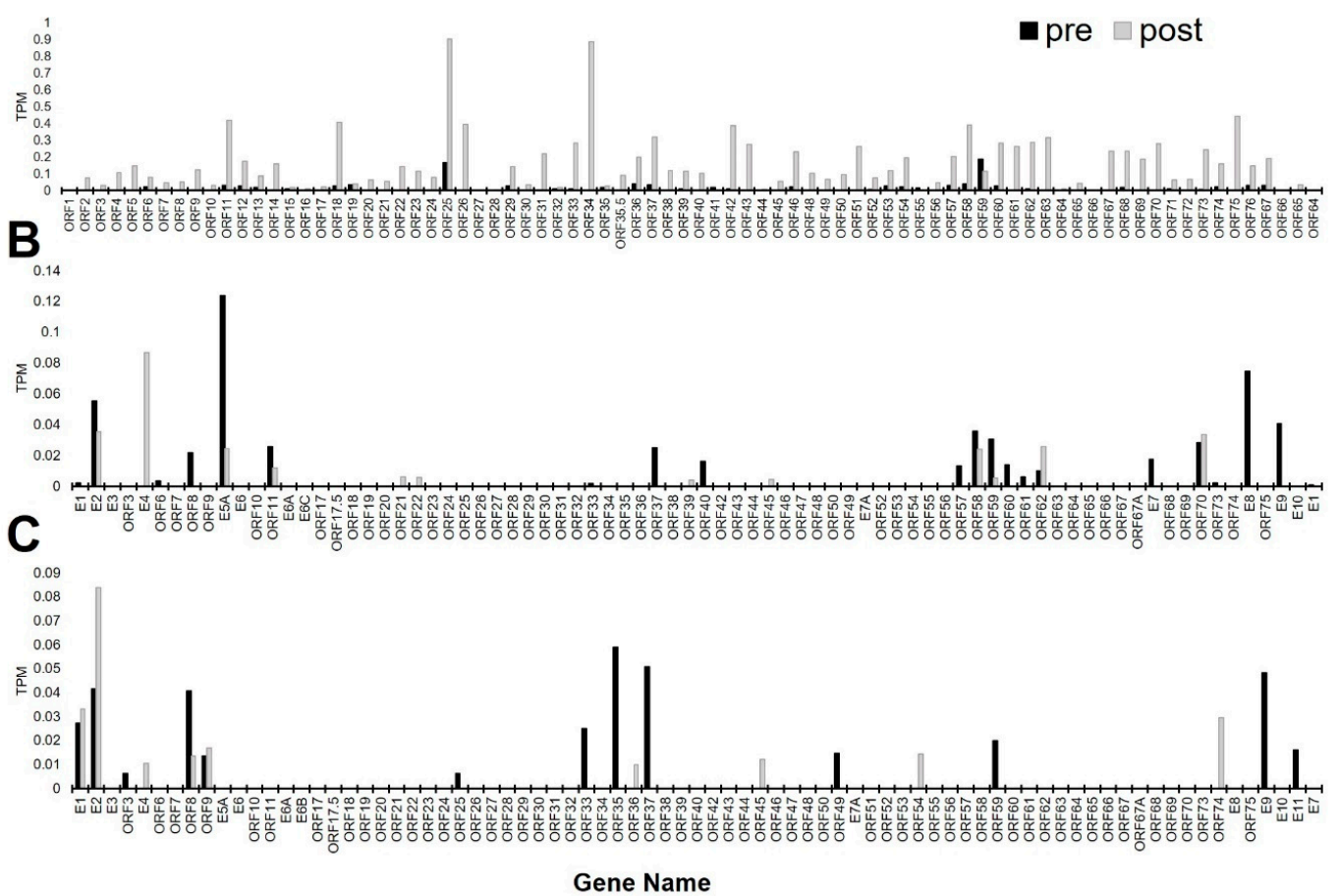

Figure 6. Normalized counts of viral genes. Data represent the average transcripts per million (TPM) of EHV-1 (A), EHV-2 (B), and EHV-5 (C). The gray line is pre-EHV-1 challenge infection, and the black line is post-EHV-1 challenge.

\subsection{Identification of miRNAs}

MiRDeep2, a software tool for miRNA mapping and identification, identified 278 known mature equine miRNAs amongst the pooled samples. Furthermore, we identified 903 total novel miRNAs with an miRDeep2 score $>1$ (File S4). Of these 903 novel miRNAs, 855 mapped to the equine genome, 57 mapped to the EHV-2 genome, and 41 mapped to the EHV-5 genome. The EHV-2 and EHV-5 miRNAs appeared to be relatively abundant given the low levels of their viral mRNA transcripts detected. The most abundant miRNA for EHV-2 had a total read count of 15,671, and for EHV-5, a count of 20,551. For EHV-2, the miRNAs clustered around three general regions on the genome: $38-44$ and $176-182 \mathrm{~kb}$ on the plus strand, and $124-127 \mathrm{~kb}$ on the minus strand. For EHV-5, the miRNAs clustered around two general regions: $36-43 \mathrm{~kb}$ on the plus strand and $126-127 \mathrm{~kb}$ on the minus strand (File S4). Interestingly, no miRNAs were identified that mapped to either of the equine alpha herpesviruses, EHV-1 or EHV-4 (File S4).

\subsection{Differential Expression of miRNAs}

Novel miRNAs with an miRDeep2 cutoff $>1$ were added to the list of known mi-RNAs for each sample and a quantification was performed to identify differentially expressed miRNAs in horses before and after EHV-1 infection. There was an average of 18,165,757 reads per sample with an average mapping of $49.7 \%$ (Table A2).

Interestingly, PCA plot analysis of these counts indicated that more variation occurred between individual horses rather than within horses as a result of infection (Figure 7A). Furthermore, there was no significant correlation between levels of viremia or EHM and miRNA expression.

However, differential expression analysis between pre-and post-infection samples revealed five total miRNAs that were differentially expressed in horses during viremia when compared to pre-infection levels (Table 3). 
Table 3. Differentially expressed miRNAs and common differentially expressed genes (predicted) to be targeted. Differentially expressed miRNAs were determined by adjusting the $p$-value $<0.05$ and $\log 2$ fold change $>|1|$. "Upregulated" refers to miRNAs upregulated during viremia compared to pre-challenge infection and "downregulated" refers to miRNAs downregulated during viremia compared to pre-challenge infection. Predicted genes to be targeted by miRNAs during viremia include only genes to be found significantly differentially regulated in our gene expression analysis (see also Table A1). A significant upregulation during viremia of those genes is indicated by $\uparrow$ and a significant downregulation is indicated by $\downarrow$.

\begin{tabular}{|c|c|c|c|c|c|c|c|}
\hline ID & Log2 Fold & Padj & MirBase ID & $\begin{array}{l}\text { Human } \\
\text { Ortholog }\end{array}$ & $\begin{array}{l}\text { Mature } \\
\text { Sequence }\end{array}$ & Precursor Sequence & $\begin{array}{c}\text { Differentially } \\
\text { Expressed Gene } \\
\text { Targets }\end{array}$ \\
\hline \multicolumn{8}{|c|}{ Upregulated miRNAs } \\
\hline $\begin{array}{l}\text { Equine_chr11 } \\
\text { _2567 }\end{array}$ & 1.2 & $3.5 \times 10^{-8}$ & eca-miR-9104 & & $\begin{array}{l}\text { CTGACCTGA } \\
\text { GGCCTCTGC } \\
\text { TGCA }\end{array}$ & $\begin{array}{l}\text { GAGTGGCTGGGC } \\
\text { TCAGCAGGGCGG } \\
\text { AGGGTCAGGAGG } \\
\text { TGAGCTTGGCTC } \\
\text { TGCTGACCTGA } \\
\text { GGCCTCTGCTGCA }\end{array}$ & \\
\hline $\begin{array}{l}\text { Equine_chrX } \\
\text { _44985 }\end{array}$ & 1.1 & $1.3 \times 10^{-17}$ & eca-miR-652 & $\begin{array}{l}\text { hsa-miR- } \\
652-3 p\end{array}$ & $\begin{array}{l}\text { AATGGCGC } \\
\text { CACTAGGG } \\
\text { TTG }\end{array}$ & $\begin{array}{l}\text { CAACCCTAGGAG } \\
\text { AGGGTGCCATTC } \\
\text { ACATAGACTATA } \\
\text { ATTGAATGGCGC } \\
\text { CACTAGGGTTG }\end{array}$ & $\begin{array}{l}\text { TNRC6A } \downarrow \text {, } \\
\text { NPTN } \uparrow, \\
\text { KPNA1 } \downarrow, \text { TP53 }\end{array}$ \\
\hline $\begin{array}{l}\text { Equine_chrX } \\
\text { _45803 }\end{array}$ & 1.1 & $2.0 \times 10^{-3}$ & eca-miR-2483 & & $\begin{array}{l}\text { TCTGTCAAC } \\
\text { CATCCAGCT } \\
\text { GTTT }\end{array}$ & $\begin{array}{l}\text { TCTGTCAACCAT } \\
\text { CCAGCTGTTTGG } \\
\text { GGTGATGCAAAC } \\
\text { AAACATCTAGTT } \\
\text { GGTTGAGAGAAT }\end{array}$ & \\
\hline \multicolumn{8}{|c|}{ Downregulated miRNAs } \\
\hline $\begin{array}{l}\text { Equine_chr15 } \\
\text { _10631 }\end{array}$ & -1 & $1.4 \times 10^{-2}$ & - & $\begin{array}{l}\text { hsa-miR- } \\
6852-5 p\end{array}$ & $\begin{array}{l}\text { ACCTGGGGA } \\
\text { TCTGAGGAG }\end{array}$ & $\begin{array}{l}\text { ACCTGGGGATCT } \\
\text { GAGGAGGCCCTT } \\
\text { CCAGCCCCAAGG } \\
\text { CTGGGAATGCTC } \\
\text { CTGGTCCCCTTT } \\
\text { CTTGC }\end{array}$ & 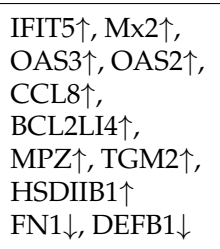 \\
\hline EHV-2_38 & -1 & $1.0 \times 10^{-2}$ & - & & $\begin{array}{l}\text { TATGATAGT } \\
\text { CCATACCCT } \\
\text { TAAGT }\end{array}$ & $\begin{array}{l}\text { TATGATAGTCCA } \\
\text { TACCCTTAAGTT } \\
\text { TGATAAGTAAAA } \\
\text { AATTTAAGTACG } \\
\text { TGGACTGTCAACA }\end{array}$ & \\
\hline
\end{tabular}

A

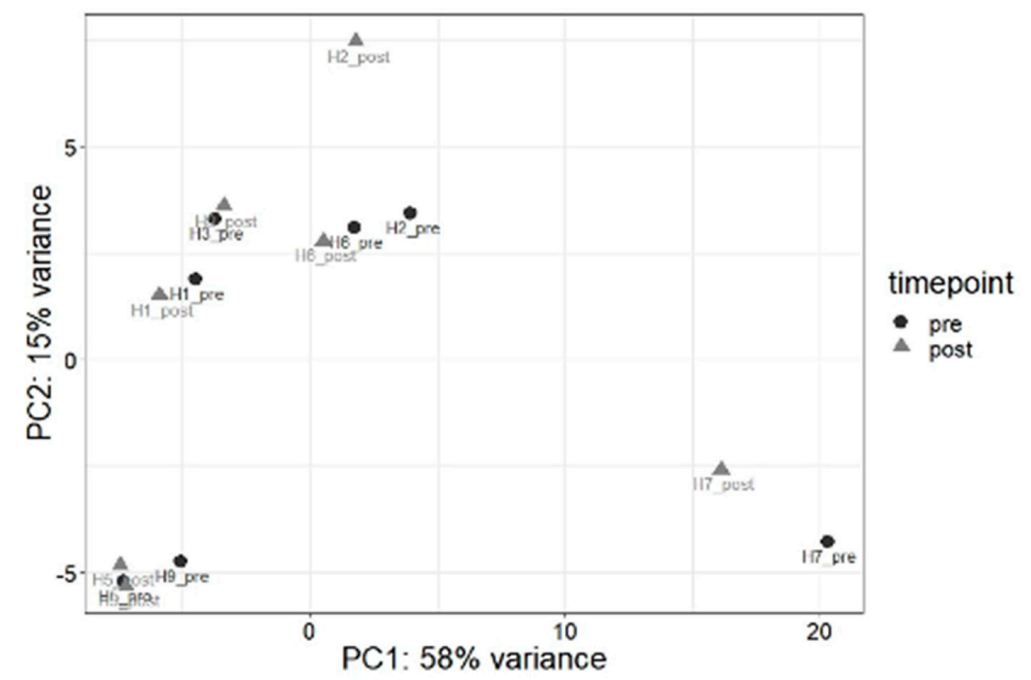

Figure 7. Cont. 

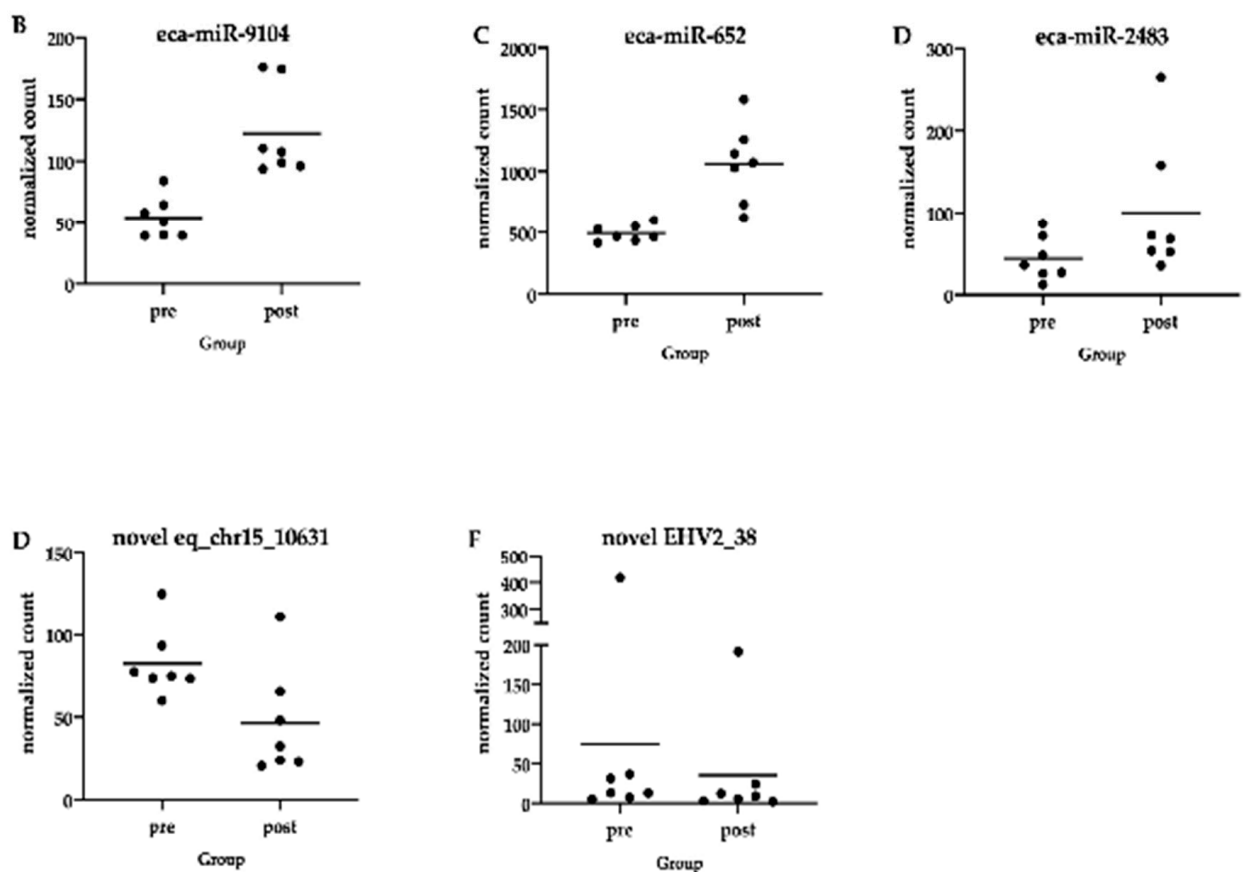

Figure 7. (A) Principal component analysis of miRNA samples. Samples cluster based on horse rather than from infection status pre-infection (black dot) vs. during infection (gray triangle). The horse numbers are indicated on the plot as H1-H9, and H3 and H5 were females. Normalized read counts of differentially expressed miRNAs. (B) eq_chr11_2567 identified with eca-miR-9104; (C) eq_chrx_44985 identified with eca-miR-652 and the human ortholog hsa-miR-652-3p; (D) eq_chrx_45803 identified with eca-miR-2483; (E) eq_chr15_10631 identified with the human ortholog hsa-miR-6852-5p;

(F) EHV-2_38 aligned to the EHV-2 viral genome. Details regarding these miRNAs can be found in Table 3.

Three of these miRNAs were upregulated in response to infection, and two were downregulated. The upregulated miRNAs included eca-miR-9104, eca-miR-2483, and ecamiR-652 (human ortholog hsa-miR-652-3p) (Figure 7B-D). Predicted target genes that were also differentially regulated in our samples included TNRC6A, NPTN, KPNA1, and TP53. TNRC6 $A$ is a regulatory gene involved in gene silencing and gene expression regulation. NPTN plays an important role in cell adhesion molecule binding and type 1 fibroblast and neurite growth. KPNA1 has been shown to play a role for nuclear import of proteins, including herpesvirus proteins [32], and TP53 plays a role in the regulation of apoptosis and cell cycle regulation. Finally, in humans, $h s a-m i R-652-3 p$ has been shown to interact with the endothelial repair gene CCND2 and contributes to endothelial cell damage [33]. While the downregulated miRNA list did not include any known equine mi-RNAs, we did identify a "novel" equine miRNA with the human ortholog hsa-miR-6852-5p to be downregulated in response to infection (Figure 7E). Interestingly, $h s a-m i R-6852-5 p$ is predicted to target a number of the differentially expressed genes in our study. These include MX2, OAS2, and OAS3, as well as IFIT5, which all belong to the interferon-stimulated genes and are important components in the defense of herpesviruses. Further differentially regulated targets include CCL8, which is an important chemokine, and a number of genes that are involved in immune defense, apoptosis, cortisol metabolism, and cell adhesion (BCL2LI4, HSD11B1, MPZ, TBM2, DEFB1, and FN1). In humans, hsa-miR-6852-5p has also been shown to induce cell cycle arrest and necrosis [34]. Perhaps even more intriguing is the fact that $h s a-m i R-6852-5 p$ is predicted to bind tetraspanins (TSPN9, TSPN11, TSPN14, TSPN15, TSPN17, TSPN18, and TSPN31) as well as many collagens. A recent paper comparing horses that developed clinical EHM with horses that did not, identified a mutation in TSPAN9 in horses with EHM in a genome-wide association study [35]. TSPAN9 is expressed in endothelial cells and platelets and stabilizes the collagen receptor in platelet microdomains [36]. While the collagen receptor plays only a minor role in hemostasis, it is important in arterial thrombosis, ischemic stroke, and maintaining vascular integrity dur- 
ing inflammation. Interestingly, we have recently found that plasma collected from horses with clinical EHM responded with decreased aggregation in response to collagen (unpublished data). Furthermore, absence of TSPAN9 in mice reduced collagen-induced activation and secretion [37]. Finally, a novel EHV-2 miRNA was also found to be downregulated in our samples (Figure 7F).

\section{Discussion}

PBMCs are an important tissue involved in the pathogenesis of EHV-1 disease both as active immune cells in addition to being the site of EHV-1 viremia and potentially latency. In this study, we sought to characterize the host and viral transcriptome of equine PBMCs prior to and during acute equine herpesvirus 1 infection. In addition, we identified miRNA expression in these cells, as they likely contribute to the tight regulation of and switch between lytic and latent infection. Using next-generation RNA sequencing (RNA seq), we were able to build an unbiased profile of equine and viral gene expression in PBMCs and determined which genes were modulated during EHV-1 viremia.

In total, 51 host genes were significantly differentially regulated in the PBMCs of horses collected during peak EHV-1 viremia when compared to PBMCs collected pre-challenge infection. As expected, we found that numerous genes involved in the interferon pathway were upregulated during EHV-1 viremia. This included many classified as interferonstimulated genes (ISGs), including OAS1, -2, and -3, OASL, MX1 and -2, IFIT3, IFIT5, IFI6, TRIM22, GBP1, and DDX60 as well as the equine miRNA miR-6852-5p targeting a number of these genes.

The type I interferon response is generally thought to occur in three phases: 1) the stimulation of pattern recognition receptors and activation of tissue factors, including $I R F 3$ and IRF7; 2) induction of interferon alpha and interferon beta expression; and 3) the continued amplification and expression of ISGs through Janus Kinase/Signal Transducer and Activator of Transcription (JAK/STAT) signaling [38,39]. Similar to the observed upregulation of ISGs, we also observed the upregulation of the transcription factor interferon regulatory factor 7 (IRF7). This gene is stimulated upon pattern recognition receptor (PRR) stimulation and is involved in the induction of the type I interferon response $[38,40]$. The type I interferon response pathway is a crucial aspect of antiviral innate immunity and is considered an important response against herpesviruses [38]. In humans, deficiencies in the responsiveness to type I interferons and the inability to induce ISGs result in death from viral infections. In one case study, an infant with a homozygous mutation in the STAT1 gene succumbed to HSV-1 infection with uncontrolled encephalitis [41]. PBMCs from patients with atopic dermatitis complicated by eczema herpeticum show significantly lower type I interferon response to ex-vivo HSV-1 infection compared to PBMCs from patients without eczema herpeticum [42]. In addition, this study found that the regulating genes IRF3 and IRF7 were also downregulated in these patients [42]. Together, these data suggest that the type I interferon response is important for protection against disease caused by alphaherpesviruses. Less is known about the importance of the type I interferon response in PBMCs from horses. In previous studies, PBMCs have been found to produce type I interferon in response to EHV-1 infection in vitro [22,23]. Similarly, in other equine cell types, type I interferon has been shown to be upregulated in response to EHV-1 infection in vitro, including respiratory epithelial cells and endothelial cells [43-48]. In our study, it was interesting to notice that the interferon alpha or interferon beta genes themselves were not upregulated, but rather the ISGs were. This was also the case in a gene expression study of human PBMCs in response to a variety of viral infections, where the authors found multiple interferon-inducible genes yet no detectable interferons [49]. Type 1 interferons are known to be quickly and transiently expressed, and so timing likely plays a role in detection of these genes. In epithelial cells, type I interferon proteins have been shown to be detectable as early as $10 \mathrm{~h}$ post-EHV- 1 inoculation in vitro and remained detectable up to $72 \mathrm{~h}$ [46]. It might also be considered that the persistence of the antiviral transcriptome is maintained without further induction of type 1 interferons. In fact, it has been 
shown that ISGs are expressed in the absence of interferon alpha/beta signaling through IRF7-mediated pathways [50]. This indicates that future studies interested in the interferon response may consider investigating downstream molecules of this pathway, such as the numerous ISGs we found here.

Another major group of genes upregulated in PBMCs during EHV-1 viremia were chemokines (CXCL9, CXCL10, CXCL11, and CCL8). More specifically, we found upregulation of chemokines to be important for induction of cell-mediated immunity and recruitment of T cells, monocytes, and natural killer (NK) cells. CXCL9, CXCL10, and CXCL11 are related chemokines that are well known for their chemotactic activity, as their receptor (CXCR3) can be found on type 1 CD4+ T helper cells, CD8+ cytotoxic lymphocytes, and NK cells [51]. Previous work has also found strong induction of these chemokines in PBMCs in response to EHV-1 infection in vitro [22]. In addition, these chemokines have been shown to be stimulated in epithelial and endothelial cell cultures following EHV-1 inoculation [52,53]. The gene encoding CCL8 (also known as monocyte chemotactic protein-2; MCP-2) was also found to be upregulated in PBMCs during EHV-1 viremia in our study in addition to $m i R-6852-5 p$, which is predicted to target CCL8. This protein, as its name suggests, is chemotactic for monocytes, as well as NK cells, T cells, eosinophils, and basophils [54]. Not much is known about the role of CCL8 during EHV-1 infection; however, it has been shown to be upregulated in endothelial cell cultures [53]. The CXCR3 ligands, as well as CCL8, are known to be induced by type II interferon (interferon gamma) [51,54]. Interferon gamma is secreted by $\mathrm{T}$ cells and NK cells and is considered a correlate of an active cell-mediated immune response $[55,56]$. Cellular immunity, particularly CD8+ $\mathrm{T}$ cells, is considered to be an important correlate of protection from EHV-1 [19,57,58]. Re-stimulation assays have found that T-cells in horses infected with EHV-1 increase interferon gamma secretion, indicative of activated $T$ cell responses [19,59-61]. The fact that all three of the CXCR3 ligands were upregulated in our samples, along with previous work, suggests that these chemokines are consistently stimulated during EHV-1 infection and that $T$ cell activation and recruitment play a role during EHV-1 infection and possibly in the protection from EHM and EHV-1 abortions. However, the exact role of these chemokines in the pathogenesis of EHV-1-mediated disease remains unknown.

A third cluster of genes with related functions in protein activation cascades were upregulated in PBMCs during EHV-1 viremia. The complement cascade is a pathway of the innate immune system that involves a series of protein activation and cleavages that enhance antibody-mediated clearance of pathogens. We found two components of this system (C1R and C3AR1) as well as an inhibitor to this cascade (SERPIN1) to all be upregulated during infection in addition to the equine miR-6852-5p, which is predicted to target $C 1 R$ ligand. EHV-1 and other herpesviruses are known to evade the complement system by "hiding" antigens within the PBMCs [62,63]. However, components of the complement system have also been shown to play a role in adaptive immunity through $B$-cell- and T-cell-related functions. The complement receptor encoded by $C 1 R$ has been shown to have a central role in B cell responses [64]. In humans, about $15 \%$ of $\mathrm{T}$ cells express $C 1 R$, and this molecule is upregulated in CD4+ and CD8+ T cells upon activation [65-67]. Similarly, C3AR1 is not expressed on naïve T-cells, but it is induced upon activation [68]. While these characteristics have not been described in equine lymphocytes, it is possible the differential regulation of these genes during EHV-1 infection corresponds with activation of lymphocytes. Additionally, the proteins involved in the complement cascade have also been shown to be associated with the coagulation cascade [69]. For example, the C1 inhibitor (SERPIN1) not only regulates the complement cascade but has also been shown to inactivate coagulation factors [70]. This is of particular interest because the coagulation cascade is known to be induced in horses during EHV-1 viremia, and it is thought that this is a major contributor to endothelial damage and subsequent immunopathology, causing secondary disease such as EHM [71-74]. Regulation of hemostasis is critical during health and disease with a tightly regulated balance between anti-coagulation and procoagulation factors. In a healthy individual, the body holds this balance towards a slight 
anti-coagulation state. However, in times of disease or vascular damage, coagulation factors are released to form a protective fibrin clot. These factors are tightly regulated so as to prevent clotting disorders $[69,75]$. Therefore, it is not surprising that we see gene expression for components (C1R and C3AR1) as well as regulators (SERPIN1) of the complement and coagulation cascades.

Upon infection with EHV-1, we observed a change in the cell fraction percent of certain cell populations. We saw a decrease in M0 macrophages and an increase in M1 macrophages, which indicates activation and polarization of macrophages to an M1 phenotype. This phenotype is believed to correspond with the antiviral and anti-inflammatory macrophage phenotype [76]. Additionally, there was an increase in $\gamma \delta$ T cells. $\gamma \delta$ T cells are known for their expression of IL-17, and while they do express a T cell receptor, they can also be stimulated via cytokines, making them similar to innate lymphoid cells [77]. During viremia, EHV-1 infects monocytes, T cells, and B cells; however, only between 1 to 10 out of $10^{7}$ PBMCs are estimated to be infected with EHV-1. Therefore, it is unlikely that drastic cell population changes are a result of EHV-1 infection of a certain subtype [11-15,78]. EHV-1 infection is marked by lymphopenia, and previous reports attributed this specifically to T cells $[79,80]$. This was confirmed by Charan et al. [80], who showed that post-EHV-1 infection autologous sera collected from horses contained increased levels of transforming growth factor beta and caused both non-specific and EHV-1-specific suppression of T cell responses. Furthermore, we have previously shown suppression of both CD4+ and CD8+ $\mathrm{T}$ cell responses in ponies on day 7 post-infection with EHV-1 [20]. In the present study, we found a decrease in CD8+ T cells during infection. CD4+ T cells were also decreased, although this decrease was not statistically significant. It is known that CD4+ type 1 helper T cells and CD8+ T cells are crucial for protection against EHV-1 disease, and the decrease in circulating PBMC population could be explained by the recruitment of these cells towards sites of infection, i.e., the nasal epithelial tissue and secondary sites of infection [19,57,58]. These results also correspond with the observed increases in the chemokine genes CXCL9, CXCL10, CXCL11, and CCL8 during peak viremia. Similarly, the reduction in plasma B cells we observed may be a sign of these cells being recruited out of circulation to the site of primary infection. We estimated cell populations using CIBERSORTx, a new tool for digital cytometry that allows for cell population estimations of heterogenous populations based on bulk RNA sequencing data [28]. It must be noted that the results from this in silico analysis should be interpreted with caution, as the estimation of cell fractions was computed using a reference file based on the transcriptome of human leukocytes that Newman et al. developed [28]. In order to generate a more accurate estimation, a reference should be generated based on the transcriptome of classically sorted equine cells. Alternatively, the expensive technology of single-cell RNA sequencing could be used to characterize gene expression in individual cells and to more precisely estimate populations.

While the majority of the PBMC transcriptome belongs to host genes, it was another goal of ours to identify which EHV-1 viral transcripts were present in the samples. It was interesting to see that many EHV-1 transcripts were identified in 5 of 7 horses prior to EHV-1 challenge, despite horses being negative for viral genome using qPCR. However, the depth of sequencing of our samples was approximately 43 million reads per sample, so we could identify low levels of viral transcription. It is possible that this depth of next-generation sequencing is more sensitive than our qPCR assay, and it is also possible that viral transcripts are more abundant in samples than latent genomic DNA. While the trigeminal ganglia is the trademark site for EHV-1 latency, many studies have reported EHV-1 latency in lymphoid tissues and PBMCs as well as in additional ganglia and lymphoid tissues [3-7]. It is presumed that most horses become infected with EHV-1 at a very young age (days to weeks old) [81-84]. While the horses used in our study were seronegative for EHV-1 serum virus neutralization (VN) antibodies prior to challenge, it is presumed that they still may have previously been exposed to the virus and established latency. We propose the transcription of EHV-1 found in the pre-infection PBMCs is from a previously acquired but clinically "latent" virus. An important distinction must be made between clinical 
latency - the period of time after an infection when the host no longer has the disease-and cellular latency - when the viral genome is present within the cell but does not produce progeny virions [1]. Cellular latency is often characterized by a restricted gene expression pattern and a characteristic latency-associated transcript. This transcript has not yet been identified for EHV-1, and we are unable to speculate whether the transcription observed in our pre-challenge samples represents true cellular latency, an "arrested" state of virus replication, or a mixture of lytic and latent gene expression patterns in different cells. However, we identified three genes that exhibited higher average expression in the prechallenge samples compared to the post-challenge samples. These included ORF59, ORF41, and ORF55. ORF59 was also the most abundant transcript overall in the pre-challenge samples. This gene encodes an early protein involved in viral growth and has been found to be essential for EHV-1 replication in culture [31]. Interestingly, ORF59 is one of a few genes without a positional homolog in HSV-1 or HSV-2. The homolog exists in other Varicelloviruses including Varicella-Zoster virus (VZV) and pseudorabies virus (PRV), and while it is essential for PRV replication, it has been found to be non-essential for VZV replication in culture $[85,86]$. The ORF25 gene was found to be relatively highly expressed in both pre- and post-challenge samples. This gene encodes a capsid protein. While not much is known about the role of this protein in EHV-1 infection, the VZV homolog (ORF23) has been found to be important for infection and lesion formation on human skin xenografts in a murine model of VZV pathogenesis [87]. During viremia, we also found ORF75 to be one of the most abundantly expressed genes. This gene is one of six genes that have been deleted from the KyA laboratory strain of EHV-1. KyA has been found to be attenuated and avirulent in horses and does not cause detectable viremia [29]. Creation of an ORF75 deletion mutant has identified that this gene is not essential for EHV-1 replication and does not alter the clinical virulence in vivo [88,89]. However, the complete function of ORF75 remains unknown.

In addition to transcription of EHV-1 genes, we found transcripts from both equine gammaherpesviruses, EHV-2 and EHV-5. This is unsurprising given that the site of persistence for these viruses is B cells $[90,91]$. Our results are also consistent with other reports that show that detection of EHV-2 and EHV-5 is common in PBMCs, while EHV-1 is predominantly detected during the viremic phase of acute EHV-1 infection [92]. Here, we found EHV-2 transcripts in samples of $4 / 7$ horses pre- and post-EHV-1 challenge. For EHV-5, transcripts were detected in $5 / 7$ pre-EHV-1 infection and in $3 / 7$ post-EHV- 1 infection samples, respectively. In a previous study of EHV-1-challenged horses, we found EHV-5 in PBMCs of $76 \%$ of horses prior to challenge infection and $52 \%$ seven and ten days postEHV-1 challenge infection [93]. It is possible that the rate of EHV-5 detection drops below the detectable limit in PBMCs during EHV-1 viremia due to increased immune activity of the circulating lymphocytes. Studies linking EHV-5 and equine lymphoma point to an important role of lymphocytes in the control of EHV-5 persistence and re-activation [94,95]. However, both EHV-2 and EHV-5 transcripts were observed during acute EHV-1 infection. It is therefore likely that the gammaherpesviruses are resilient and persistent in this site of latency, even in the face of systemic immunity.

Notably, no miRNAs mapped to the EHV-1 genome prior to or during EHV-1 viremia. However, we identified 98 total miRNAs mapping to the two gammaherpesvirus genomes. MiRNAs are known to be involved in herpesvirus biology and the establishment of latency [26]. The differences we observed in miRNA between the gammaherpesviruses EHV-2 and EHV-5 and the alphaherpesvirus EHV-1 may be explained by the differences in these subfamilies' latency tropism. The classical theory of herpesvirus biology describes sensory ganglia as the primary target for latency of alphaherpesviruses and lymphocytes as the primary latency site for gammaherpesviruses [1]. While several reports have identified lymphoid tissues as a site of latency for EHV-1, genome detection in circulating PBMC via qPCR is often negative in non-clinically affected animals [3-7,96]. In contrast, EHV-2 and EHV-5 can be routinely detected in PBMC samples of healthy animals [96,97]. This indi- 
cates that these two subfamilies employ differing transcription strategies in latency and persistence in lymphocytes, likely including the use of miRNA transcription.

In contrast to mRNA gene expression, we found very few differentially expressed hosts or viral miRNAs in this study. Five significantly differentially expressed miRNAs were detected, two of which had human orthologs identified. Target prediction was only successful for the two miRNAs with human orthologs. Of those, one was upregulated (eca-miR-652) and predicted targets for differentially regulated genes in our samples for this miRNA included TNRC6A, a regulatory gene involved in gene silencing and gene expression regulation; NPTN, which plays an important role in cell adhesion molecule binding; KPNA1, which has been shown to play a role for nuclear import of proteins, including herpesvirus proteins [32], and TP53, which plays a role in the regulation of apoptosis and cell cycle regulation. Finally, in humans, $h s a-m i R-652-3 p$ has been shown to interact with the endothelial repair gene CCND2 and contributes to endothelial cell damage [33]. The other differentially regulated equine miRNA with the human ortholog $h s a-m i R-6852-5 p$ was downregulated in response to infection. Interestingly, this miRNA is predicted to target a number of the differentially regulated identified target genes in our study which belong to the interferon-stimulated genes and are important components in the defense of herpesviruses. Further differentially regulated targets included the C1R ligand, which is part of the complement activation cascade; CCL8, an important chemokine, and a number of genes involved in apoptosis, cortisol metabolism, and cell adhesion. Even more intriguing is the fact that $h s a-m i R-6852-5 p$ is predicted to bind tetraspanins (TSPN9, TSPN11, TSPN14, TSPN15, TSPN17, TSPN18, and TSPN31) as well as many collagens. A recent paper comparing horses that developed clinical EHM with horses that did not, identified a mutation in TSPAN9 in horses with EHM in a genome-wide association study [35]. TSPAN9 is expressed in endothelial cells and platelets and stabilizes the collagen receptor in platelet microdomains [36]. While the collagen receptor plays only a minor role in hemostasis, it is important in arterial thrombosis, ischemic stroke, and maintaining vascular integrity during inflammation. Interestingly, we have recently found that plasma collected from horses with clinical EHM responded with decreased aggregation in response to collagen (unpublished data). Furthermore, absence of TSPAN9 in mice reduced collagen-induced activation and secretion [37]. While none of the predicted TSPAN or collagen genes were identified as differentially regulated in our samples, our study used PBMCs, which do not contain platelets or endothelial cells. However, both platelets and vascular endothelial cells are in direct contact with EHV-1-infected PBMCs during EHM pathogenesis and this interaction is likely an important aspect of the EHM pathogenesis. Interestingly, the human ortholog hsa-miR-652-3p is known to contribute to endothelial damage, and knockdown of this miRNA has been shown to promote endothelial cell repair [33]. Clearly, further investigation of this miRNA, its predicted targets in horses, and its role in EHM development in different tissue compartments would be interesting.

In conclusion, we characterized the transcriptome of equine PBMCs pre- and postEHV-1 challenge infection using a repeated measure design. We used RNA deep sequencing to comprehensively investigate equine mRNA and miRNA transcripts, as well as those from four common equine herpesviruses, EHV-1, EHV-2, EHV-4, and EHV-5. Notably, after gene expression analysis, we were able to characterize the immune response of PBMCs during viremia and found significant upregulation of multiple genes involved in processes including the interferon pathway, $\mathrm{T}$ cell chemotaxis, and protein activation cascades such as the complement and coagulation system. More work is needed to fully elucidate how these mechanisms are involved in either protection from or contribution to EHV-1-associated secondary diseases such as abortion and EHM. Nevertheless, this work expands our current knowledge about the role of PBMCs during EHV-1 viremia and will inform the focus on future experiments to identify host and viral factors that contribute to clinical EHM. 


\section{Materials and Methods}

\subsection{Viruses}

EHV-1 strain Ab4 (NCBI RefSeq: NC_001491.2) was propagated in equine dermal (NBL-6) cells (ATCC ${ }^{\circledR}$ CCL-57 ${ }^{\mathrm{TM}}$ ) with MEM-10 (Minimum Essential Medium Eagle (SigmaAldrich, St. Louis, MO, USA) supplemented with $100 \mathrm{IU} / \mathrm{mL}$ penicillin, $100 \mu \mathrm{g} / \mathrm{mL}$ streptomycin, 1\% GlutaMAX (GIBCO, Life Technologies, Carlsbad, CA, USA), $1 \mathrm{mM}$ sodium pyruvate, $1 \%$ non-essential amino acids (M7145, Sigma-Aldrich), and $10 \%$ fetal bovine serum. After incubation at $37^{\circ} \mathrm{C}$ and $5 \% \mathrm{CO}_{2}$ for $3-4$ days, the cells were frozen and thawed, and cellular debris was removed by centrifugation at $300 \times g$ for $10 \mathrm{~min}$. The stock was stored at $-80^{\circ} \mathrm{C}$. Prior to inoculation in horses, the stock was thawed and sonicated for three cycles of $30 \mathrm{~s}$ at 50-1 amplification and diluted to a titer of $10^{6}$ plaque-forming units (PFU)/mL for inoculation of horses.

\subsection{Animals}

Seven 1-year-old horses ( 5 males, 2 females) were used in this experiment. Horses were screened prior to inclusion in the study to ensure virus neutralization assay (VN) blood serum titers were below 1:4 for EHV-1 and below 1:24 for EHV-4. Animals were housed in a building with natural ventilation with multiple horses per pen and nose-to-nose contact between pens. The horses had access to grass hay and water ad libitum for the entirety of the study. All animal maintenance and procedures were performed in compliance with Michigan State University's Institutional Animal Care and Use Committee.

\subsection{Experiment Design}

The horses used in this study were part of a separate experiment evaluating the use of a human adenovirus vector expressing the EHV-1 inhibitory gene, IR2, for prevention of nasal viral shedding [27]. In this study, horses received intranasal instillation of either $3 \times 10^{10}$ particles of a human adenovirus vector expressing the EHV-1 IR2 protein $\left(n=3 ; 2\right.$ males, 1 female) or $1.5 \times 10^{10}$ particles of a null adenovirus vector $(n=4 ; 3$ males, 1 female) by intranasal instillation two days prior to EHV-1 challenge [27]. Because no effect was observed as a result of IR2 treatment in any of the clinical, virological, or immunological parameters evaluated, for the purpose of the current study, all horses were considered as one group [27]. Horses were challenged with $5 \times 10^{7}$ plaque-forming units (PFU) of EHV-1 Ab4 via intranasal instillation.

\subsection{Sample Collection}

To ensure we had samples for each horse's day of peak viremia, $100 \mathrm{~mL}$ of whole blood was collected into heparinized syringes via jugular venipuncture from all horses 13 days prior to experimental infection with EHV-1 and daily for 10 days post-challenge infection. Samples were immediately transported back to the laboratory for PBMC isolation. For isolation of RNA and library preparation, PBMCs were separated by density gradient centrifugation over Histopaque-1077 (Sigma-Aldrich) as previously described [20] and cell pellets of $6 \times 10^{7}$ were stored at $-80^{\circ} \mathrm{C}$ until RNA isolation. An additional aliquot of $1 \times 10^{7}$ PBMCs was stored at $-80^{\circ} \mathrm{C}$ for quantification of viremia using qPCR as previously described [21]. The day after challenge for peak viral load in PBMCs was determined for each horse. Additionally, physical exams to evaluate respiratory disease and rectal body temperature were performed daily and nasal swabs were collected for viral quantification using qPCR, as previously described [21].

\subsection{RNA Isolation, Library Preparation, and Sequencing}

A summary of the data analysis can be seen in Figure 8. RNA for RNA sequencing analysis was isolated from PBMCs from each horse pre-challenge, as well as on the day of peak viremia. Cell pellets were lysed and homogenized using TRIzol Reagent (Thermo Fisher) following the manufacturer's instructions. The aqueous phase was then collected, washed with $100 \%$ ethanol, and total RNA was isolated using the miRNeasy Mini Kit 
(Qiagen) according to the manufacturer's instructions. To eliminate genomic DNA contamination, a deoxyribonuclease treatment (Qiagen) was applied to each sample according to the manufacturer's recommendation. The concentration of RNA was determined using fluorometric quantification with Qubit 1.0. RNA quality was evaluated using the Agilent 2100 Bioanalyzer with the RNA 6000 Pico Assay, and samples with an RNA integrity number (RIN) score $\geq 8.90$ were submitted for sequencing. Library preparation and next-generation sequencing were performed at Michigan State University's Genomics Research and Technology Support Facility. Briefly, stranded mRNA cDNA library preparation was preformed using the Illumina TruSeq Stranded mRNA kit with Integrated DNA Technologies (IDT) for Illumina Unique Dual Index adapters according to the manufacturer's recommendations. miRNA cDNA libraries were prepared using the Illumina TruSeq Small RNA Library Preparation Kit following the manufacturer's recommendations. Completed libraries were quality-controlled and quantified using a combination of Qubit dsDNA HS and Advanced Analytical Fragment Analyzer High Sensitivity DNA assays. The mRNA libraries were pooled in equimolar quantities for sequencing and the pool was quantified using the Kapa Biosystems Illumina Library Quantification qPCR kit. This pool was loaded onto two (2) lanes of an Illumina HiSeq 4000 flow cell and sequencing was performed in a $2 \times 150 \mathrm{bp}$ paired-end format using HiSeq 4000 styrene-butadiene-styrene (SBS) reagents. The small libraries were pooled in equimolar amounts for multiplexed sequencing and the pool was quantified using the Kapa Biosystems Illumina Library Quantification qPCR kit. This pool was loaded onto one (1) lane of an Illumina HiSeq 4000 flow cell and sequencing was performed in a $1 \times 50 \mathrm{bp}$ single read format using HiSeq 4000 SBS reagents. Base calling was done using Illumina Real-Time Analysis (RTA) v2.7.7 and output of RTA was demultiplexed and converted to FastQ format with Illumina Bcl2fastq v2.19.1. All raw sequencing reads are available in the National Center for Biotechnology Information (NCBI) sequence read archive (SRA) under BioProject Ascension number PRJNA681404.

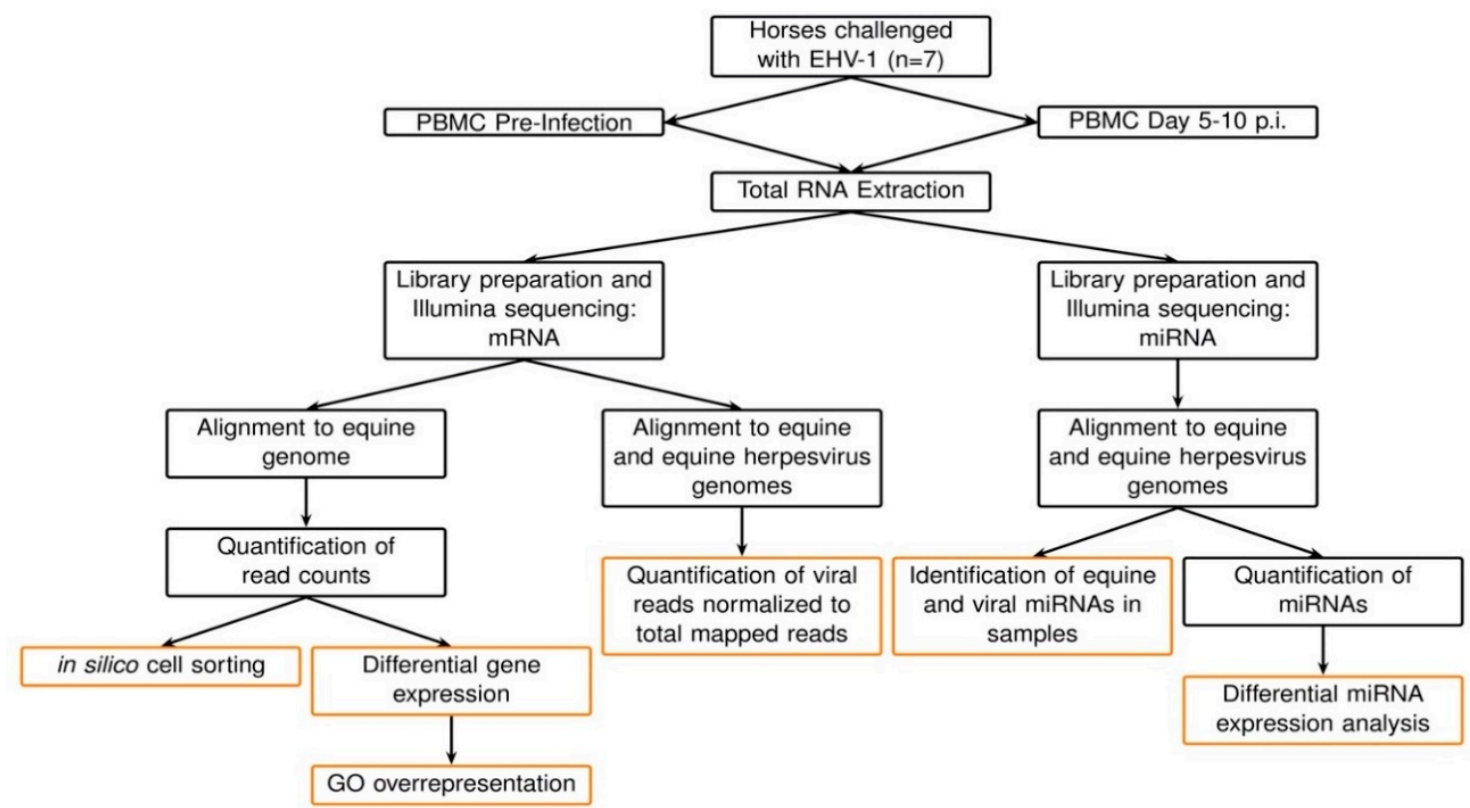

Figure 8. Summary of data analysis. RNA was extracted from PBMCs from horses prior to and during EHV-1 challenge infection. Total RNA was processed with next-generation RNA sequencing for mRNA and miRNA. Black boxes represent upstream data analysis processes, while the red boxes represent processes that resulted in output reported in the results.

\subsection{Genome-Guided mRNA Alignment}

Read quality was assessed using FastQC software v0.11.7. Reads were mapped to the Equus caballus genome (assembly EquCab3.0, ENSEMBL release-95) using HISAT2v 
2.1.0. with these options: -rna-strandness RF -dta. The accepted hits' BAM files were sorted by name using SAMtools v1.5 and read counts were generated using htseq-count (built in with Python v3.6.4) with the following options: -format=bam, -stranded = reverse, and - order $=$ name [98-100]. The reference annotation GTF file was downloaded from Ensembl release 95.

\subsection{Host and Viral miRNA Identification and Quantification}

Read quality was assessed before and after quality and adaptor trimming using FastQC software v0.11.7 [101]. Raw reads were trimmed using cutadapt v1.16. Options included trimming the Illumina adaptor sequence (option -a TGGAATTCTCGGGTGC-

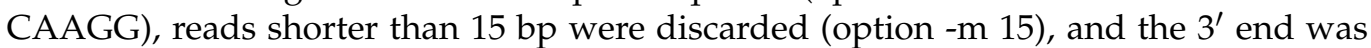
trimmed with a quality score cutoff of 20 (option -q 20) [102]. After trimming, miRDeep2 v2.0.0.8 was used to identify all miRNAs present in the samples, including putative novel miRNAs as well as known miRNAs [103]. For this, reads from all samples were first pooled. Next, a combined reference genome was created from combining the horse (EquCab3.0; downloaded from Ensembl release 95) with the genome of the four most common equine herpesviruses (EHV-1, NCBI RefSeq NC_001491.2; EHV-2, NCBI RefSeq NC_001650.2; EHV-4, NCBI RefSeq NC_001844.1; and EHV-5, NCBI RefSeq NC_026421.1) and indexed using the bowtie-build function of Bowtie v1.2.2. The mapper.pl function of miRDeep2 was used on the pooled reads to the reference genome to create a fasta file with processed reads and an arf file with mapped reads. Next, the miRDeep2.pl function was performed on these outputs using equine miRNAs as the main reference. Since the equine miRNA database is still very incomplete, mouse and human known miRNAs were used as related species lists. Known equine, mouse, and human miRNAs were downloaded from the miRbase database (release 22.1) [104]. Novel RNAs with an miRDeep score $<1$ were removed for subsequent analysis.

In order to perform differential gene expression analysis, the miRNAs were quantified in each sample. For this, the quantifier.pl tool from the miRDeep2 package was used. For this, all novel mature and precursor miRNAs were added to the list of known miRNAs from horse, mouse, and human. Quantifier.pl was run with the processed reads fasta file as input and the $-\mathrm{k}$ option was used to consider precursor mature mappings that have different IDs.

\subsection{Differential Gene Expression}

Differential gene expression analyses for both mRNA gene counts and miRNA counts were performed using the DESeq2 package v1.22.2 in R v3.5.3 [105]. The design formula used was " horse + timepoint" so that the variable of interest was "timepoint" (preinfection vs. post-infection) and controlling for the effect of "horse". Genes or miRNAs with less than 5 total read counts were filtered out prior to analysis. The default DESeq2 analysis was performed using the DESeq function. p-values were adjusted using the Benjamini-Hochberg method (the default for DESeq2). Significance was set at adjusted p-value (padj) $<0.05$ and $\log 2$ fold change $>$ | 3 | for mRNA and padj $<0.05$ and $\log 2$ fold change $>|1|$ for miRNA.

\subsection{Gene Enrichment Analysis}

A gene enrichment analysis for gene ontology (GO) terms was performed on the gene lists derived from the differential expression analysis. Horse Ensembl IDs were converted to gene symbols based on the gene names identified in the EquCab3.0 GTF file (Ensembl release 95). A GO enrichment analysis for biological processes was performed using the enrichGO function from the clusterProfiler package [106]. The database used was the human "org.Hs.eg.db", and the background was created from the gene symbols associated with all genes present in our samples [107]. p-values were adjusted using the BenjaminiHochberg correction and statistical significance was set at $p<0.05$. After generating lists of enriched GO terms, redundant terms were removed using REVIGO [108]. Enriched 
GO terms along with their associated adjusted p-values were provided as inputs, and the allowed similarity was small (0.5). The default settings were used, which included selecting the whole UniProt database to determine GO term sizes and using the SimRel semantic similarity measure for the analysis.

\subsection{Target Gene Analysis of Differentially Expressed miRNAs}

A target gene analysis of the 2 differentially expressed miRNAs with an identified human ortholog was conducted using TargetScan Release v.7.2 [109]. The other identified differentially expressed miRNAs did not result in any predicted target genes as no human ortholog could be identified with our analysis. Predicted target genes for miRNAs with human orthologs were compared with the differentially expressed gene list (Table A1 in Appendix A).

\subsection{Viral Gene Identification and Counting}

In order to identify viral reads within the samples, a combined reference genome was created from combining the horse (EquCab3.0; Ensembl release 95) with the genome of the four most commonly studied equine herpesviruses (EHV-1, NCBI RefSeq NC_001491.2; EHV-2, NCBI RefSeq NC_001650.2; EHV-4, NCBI RefSeq NC_001844.1; and EHV-5, NCBI RefSeq NC_026421.1). This allowed for subsequent normalization of viral read counts to consider total gene expression from the host. Alignment to this genome was performed for each sample using HISAT2, as described above. Gene counts were then generated using StringTie v1.3.5 as described in the StringTie manual (accessed June 2020) [100]. Initially, gene counts were generated for each sample using the equine reference GTF file. Then, a new annotation in GTF format was generated based on the genes and transcripts present in our samples. Finally, the BAM file for each sample was re-run with StringTie to generate gene counts for each sample using the new merged GTF file as the reference annotation and included the -B and -e options. Transcripts per million (TPM) values for each gene were extracted from the gene abundance files generated using the -A option. Raw read coverages of samples on the EHV-1 genome were visualized using Integrative Genomics Viewer (IGV) v2.4.10 [110].

\subsection{In Silico Cell Sorting}

Normalized read counts expressed as counts per million (CPM) were determined using EdgeR v3.24.3 and values of redundant genes were merged together [111]. Cell fractions were imputed using CIBERSORTx [28]. The included LM22 (22 immune cell types based on human immune cell gene signatures) was used as the signature matrix file. The mixture file included the CPM values for each gene from all samples, identified with gene symbol. B-mode batch correction was performed, and quantile normalization was disabled (recommended for RNA sequencing data). Permutations for significance analysis were set at 100. The run was performed in relative mode (default). Each cell type was represented as a percentage of total cells for each sample, and a Wilcoxon signed rank test was performed on the percentages for each cell type using $\mathrm{R}$.

Supplementary Materials: The following are available online at https: / / www.mdpi.com/2076-081 7/10/1/43/s1, File S1, File S2, File S3, and File S4.

Author Contributions: Conceptualization, L.M.Z., P.S.D.W., and G.S.H.; experiment and sample collection, L.M.Z., and Y.L.; computational data analysis, L.M.Z.; writing - original draft preparation, L.M.Z. and G.S.H.; writing-review and editing, all authors; funding acquisition, P.S.D.W. and G.S.H. All authors have read and agreed to the published version of the manuscript.

Funding: This research was funded by the Michigan State University College of Veterinary Medicine's Endowed Research Fund and the Freeman Fund for Equine Research.

Institutional Review Board Statement: All animal maintenance and procedures were performed in compliance with Michigan State University's Institutional Animal Care and Use Committee protocol number AUF: 04/17-061-00. 
Data Availability Statement: Raw sequencing reads used for the data analysis in this study are available in the National Center for Biotechnology Information (NCBI) sequence read archive (SRA) under BioProject Ascension number PRJNA681404.

Acknowledgments: The authors would like to thank the following colleagues and facilities for their help with this study. David O'Daniel managed the animal facilities. Allison McCauley, Rachel Baumgardner, Julie Dau, and Elis Fisk assisted with animal husbandry and sample collection. Emily Crisovan and the Genomics Research and Technology Support Facility at Michigan State University assisted with technical advice and performed the library preparation and next-generation sequencing. The Institute for Cyber-Enabled Research at Michigan State University provided the computational resources.

Conflicts of Interest: The authors declare no conflict of interest.

\section{Appendix A}

Table A1. Differentially expressed genes.

\begin{tabular}{|c|c|c|c|c|}
\hline Symbol & $\begin{array}{l}\text { Log2 Fold } \\
\text { Change }\end{array}$ & Padj & $\begin{array}{c}\text { PANTHER } \\
\text { Family/Subfamily }\end{array}$ & Function-UniProtKB (Homo sapiens Ortholog) \\
\hline \multicolumn{5}{|c|}{ Upregulated genes } \\
\hline ENSECAG00000034754 & 6.4 & $3.8 \times 10^{-22}$ & $\begin{array}{l}\text { Interferon-induced } \\
\text { transmembrane protein } 3 \\
\text { (PTHR13999:SF4) }\end{array}$ & No UniProtKB function listed. \\
\hline DDX60 & 6.1 & $1.1 \times 10^{-65}$ & $\begin{array}{l}\text { ATP-dependent RNA } \\
\text { helicase DDX60-related } \\
\text { (PTHR44533:SF3) }\end{array}$ & $\begin{array}{l}\text { Positively regulates DDX58/RIG-I- and } \\
\text { IFIH1/MDA5-dependent type I interferon and } \\
\text { interferon-inducible gene expression in response to } \\
\text { viral infection. }\end{array}$ \\
\hline $\mathrm{MX} 2$ & 5.8 & $1.4 \times 10^{-64}$ & $\begin{array}{l}\text { Interferon-induced } \\
\text { GTP-binding protein MX2 } \\
\text { (PTHR11566:SF46) }\end{array}$ & $\begin{array}{l}\text { Interferon-induced dynamin-like GTPase with } \\
\text { potent antiviral activity against human } \\
\text { immunodeficiency virus type } 1 \text { (HIV-1). }\end{array}$ \\
\hline APOBEC3Z1B & 5.8 & $1.8 \times 10^{-7}$ & $\begin{array}{l}\text { DNA DC-DU-editing } \\
\text { enzyme APOBEC-3G } \\
\text { (PTHR13857:SF20) }\end{array}$ & No UniProtKB function listed. \\
\hline ENSECAG00000032492 & 5.0 & $1.7 \times 10^{-52}$ & $\begin{array}{l}\text { Subfamily not named } \\
\text { (PTHR44533:SF5) }\end{array}$ & No UniProtKB function listed. \\
\hline CXCL9 & 4.8 & $5.7 \times 10^{-34}$ & $\begin{array}{l}\text { C-X-C motif chemokine } 9 \\
\text { (PTHR10179:SF44) }\end{array}$ & $\begin{array}{l}\text { Cytokine that affects the growth, movement, or } \\
\text { activation state of cells that participate in immune } \\
\text { and inflammatory response. Chemotactic for } \\
\text { activated T cells. }\end{array}$ \\
\hline NRGN & 4.6 & $8.6 \times 10^{-4}$ & None & $\begin{array}{l}\text { Acts as a "third messenger" substrate of protein } \\
\text { kinase C-mediated molecular cascades during } \\
\text { synaptic development and remodeling. Binds to } \\
\text { calmodulin in the absence of calcium. }\end{array}$ \\
\hline TNFSF15 & 4.5 & $4.9 \times 10^{-4}$ & $\begin{array}{l}\text { Tumor necrosis factor } \\
\text { ligand superfamily } \\
\text { member } 15 \\
\text { (PTHR11471:SF24) }\end{array}$ & $\begin{array}{l}\text { Mediates activation of NF-kappa-B. Inhibits } \\
\text { vascular endothelial growth and angiogenesis } \\
\text { (in vitro). Promotes activation of caspases } \\
\text { and apoptosis. }\end{array}$ \\
\hline ENSECAG00000004433 & 4.5 & $1.5 \times 10^{-70}$ & $\begin{array}{l}\text { Interferon-induced protein } \\
\text { with tetratricopeptide } \\
\text { repeats } 1 \\
\text { (PTHR10271:SF30) }\end{array}$ & No UniProtKB function listed. \\
\hline ENSECAG00000015137 & 4.4 & $1.5 \times 10^{-3}$ & $\begin{array}{c}\text { Granzyme B } \\
\text { (PTHR24271:SF53) }\end{array}$ & No UniProtKB function listed. \\
\hline CXCL11 & 4.4 & $1.5 \times 10^{-7}$ & $\begin{array}{l}\text { C-X-C motif chemokine } 11 \\
\text { (PTHR10179:SF28) }\end{array}$ & $\begin{array}{l}\text { Chemotactic for interleukin-activated T cells but } \\
\text { not unstimulated T cells, neutrophils, or monocytes. }\end{array}$ \\
\hline C3AR1 & 4.4 & $1.6 \times 10^{-5}$ & $\begin{array}{l}\text { C3A anaphylatoxin } \\
\text { chemotactic receptor } \\
(\text { PTHR24225:SF28) }\end{array}$ & $\begin{array}{l}\text { Receptor for the chemotactic and inflammatory } \\
\text { peptide anaphylatoxin C } 3 \text { a. This receptor } \\
\text { stimulates chemotaxis, granule enzyme release, } \\
\text { and superoxide anion production. }\end{array}$ \\
\hline
\end{tabular}


Table A1. Cont.

\begin{tabular}{|c|c|c|c|c|}
\hline Symbol & $\begin{array}{l}\text { Log2 Fold } \\
\text { Change }\end{array}$ & Padj & $\begin{array}{c}\text { PANTHER } \\
\text { Family/Subfamily }\end{array}$ & Function-UniProtKB (Homo sapiens Ortholog) \\
\hline CXCL10 & 4.3 & $3.9 \times 10^{-21}$ & $\begin{array}{l}\text { C-X-C motif chemokine } 10 \\
\text { (PTHR10179:SF47) }\end{array}$ & $\begin{array}{l}\text { Pro-inflammatory cytokine that is involved in } \\
\text { a wide variety of processes such as chemotaxis, } \\
\text { differentiation, and activation of peripheral } \\
\text { immune cells, regulation of cell growth, apoptosis, } \\
\text { and modulation of angiostatic effects. Thereby } \\
\text { plays an important role during viral infections by } \\
\text { stimulating the activation and migration of } \\
\text { immune cells to the infected sites. }\end{array}$ \\
\hline
\end{tabular}

\begin{tabular}{ccccc}
\hline ENSECAG00000001555 & 4.3 & $5.4 \times 10^{-4}$ & $\begin{array}{c}\text { Metallothionein-2 } \\
\text { (PTHR23299:SF24) }\end{array}$ & No UniProtKB function listed. \\
\hline ENSECAG00000032756 & 4.3 & $1.4 \times 10^{-7}$ & $\begin{array}{c}\text { DNA DC-DU-editing } \\
\text { enzyme APOBEC-3G } \\
\text { (PTHR13857:SF20) }\end{array}$ & No UniProtKB function listed. \\
\hline SAMD9L & 4.2 & $5.3 \times 10^{-53}$ & $\begin{array}{c}\text { Sterile alpha motif } \\
\text { domain-containing } \\
\text { protein 9-like } \\
\text { (PTHR16155:SF18) }\end{array}$ & $\begin{array}{c}\text { May be involved in endosome fusion. Mediates } \\
\text { downregulation of growth factor signaling via } \\
\text { internalization of growth factor receptors. }\end{array}$ \\
\hline
\end{tabular}

\begin{tabular}{|c|c|c|c|c|}
\hline MX1 & 4.2 & $5.8 \times 10^{-79}$ & & $\begin{array}{l}\text { Interferon-induced dynamin-like GTPase with } \\
\text { antiviral activity against a wide range of RNA } \\
\text { viruses and some DNA viruses. }\end{array}$ \\
\hline BCL2L14 & 4.0 & $7.4 \times 10^{-8}$ & $\begin{array}{l}\text { Apoptosis facilitator } \\
\text { BCL-2-like protein } 14 \\
\text { (PTHR14965:SF1) }\end{array}$ & Plays a role in apoptosis. \\
\hline GBP1 & 3.9 & $2.2 \times 10^{-56}$ & $\begin{array}{l}\text { Guanylate-binding protein } \\
1 \text { (PTHR10751:SF96) }\end{array}$ & $\begin{array}{l}\text { Hydrolyzes GTP to GMP in two consecutive } \\
\text { cleavage reactions. Exhibits antiviral activity } \\
\text { against influenza virus. Promotes oxidative killing } \\
\text { and delivers antimicrobial peptides to } \\
\text { autophagolysosomes, providing broad host } \\
\text { protection against different pathogen classes. }\end{array}$ \\
\hline ACOD1 & 3.9 & $5.5 \times 10^{-39}$ & $\begin{array}{l}\text { Cis-Aconitate } \\
\text { Decarboxylase } \\
\text { (PTHR16943:SF11) }\end{array}$ & $\begin{array}{l}\text { Involved in the inhibition of the inflammatory } \\
\text { response. Acts as a negative regulator of the } \\
\text { Toll-like receptor (TLRs-mediated inflammatory } \\
\text { innate response by stimulating the tumor necrosis } \\
\text { factor alpha-induced protein TNFAIP3 expression } \\
\text { via reactive oxygen species (ROS) in LPS-tolerized } \\
\text { macrophages. Involved in antimicrobial response } \\
\text { of innate immune cells; ACOD1-mediated itaconic } \\
\text { acid production contributes to the antimicrobial } \\
\text { activity of macrophages. }\end{array}$ \\
\hline IFIT3 & 3.9 & $8.2 \times 10^{-91}$ & $\begin{array}{l}\text { Interferon-induced protein } \\
\text { with tetratricopeptide } \\
\text { repeats } 3 \text { (PTHR10271:SF3) }\end{array}$ & $\begin{array}{l}\text { IFN-induced antiviral protein which acts as } \\
\text { an inhibitor of cellular as well as viral processes, } \\
\text { cell migration, proliferation, signaling, } \\
\text { and viral replication. }\end{array}$ \\
\hline $\mathrm{C} 1 \mathrm{R}$ & 3.8 & $2.3 \times 10^{-19}$ & $\begin{array}{l}\text { Complement C1R } \\
\text { subcomponent } \\
\text { (PTHR24255:SF25) }\end{array}$ & $\begin{array}{l}\mathrm{C} 1 \mathrm{r} \text { B chain is a serine protease that combines with } \\
\mathrm{C} 1 \mathrm{q} \text { and } \mathrm{C} 1 \mathrm{~s} \text { to form } \mathrm{C} 1 \text {, the first component of the } \\
\text { classical pathway of the complement system. }\end{array}$ \\
\hline ALPK1 & 3.8 & $2.2 \times 10^{-3}$ & $\begin{array}{l}\text { Alpha-protein kinase } 1 \\
\text { (PTHR46747:SF1) }\end{array}$ & $\begin{array}{l}\text { Serine/threonine-protein kinase that detects } \\
\text { bacterial pathogen-associated molecular pattern } \\
\text { metabolites (PAMPs) and initiates an innate } \\
\text { immune response, a critical step for pathogen } \\
\text { elimination and engagement of adaptive immunity. }\end{array}$ \\
\hline ENSECAG00000028889 & 3.6 & $3.3 \times 10^{-4}$ & $\begin{array}{l}\text { Metallothionein-2 } \\
\text { (PTHR23299:SF24) }\end{array}$ & No UniProtKB function listed. \\
\hline IFI44 & 3.6 & $1.2 \times 10^{-100}$ & $\begin{array}{l}\text { Interferon-induced protein } \\
44 \text { (PTHR14241:SF3) }\end{array}$ & $\begin{array}{l}\text { This protein aggregates to form } \\
\text { microtubular structures. }\end{array}$ \\
\hline ENSECAG00000033029 & 3.6 & $8.0 \times 10^{-15}$ & $\begin{array}{l}\text { Interferon-induced protein } \\
\text { with tetratricopeptide } \\
\text { repeats 1B } \\
\text { (PTHR10271:SF16) }\end{array}$ & No UniProtKB function listed. \\
\hline
\end{tabular}


Table A1. Cont.

\begin{tabular}{|c|c|c|c|c|}
\hline Symbol & $\begin{array}{l}\text { Log2 Fold } \\
\text { Change }\end{array}$ & Padj & $\begin{array}{c}\text { PANTHER } \\
\text { Family/Subfamily }\end{array}$ & Function-UniProtKB (Homo sapiens Ortholog) \\
\hline HSD11B1 & 3.5 & $1.1 \times 10^{-11}$ & $\begin{array}{c}\text { Corticosteroid } \\
\text { 11-Beta-dehydrogenase } \\
\text { isozyme } 1 \\
\text { (PTHR44279:SF1) }\end{array}$ & $\begin{array}{l}\text { Reversibly catalyzes the conversion of cortisol to } \\
\text { the inactive metabolite cortisone. }\end{array}$ \\
\hline OAS1 & 3.5 & $5.4 \times 10^{-79}$ & $\begin{array}{l}2^{\prime}-5^{\prime} \text {-oligoadenylate } \\
\text { synthase } 1 \\
\text { (PTHR11258:SF13) }\end{array}$ & $\begin{array}{l}\text { Interferon-induced dsRNA-activated antiviral } \\
\text { enzyme which plays a critical role in cellular innate } \\
\text { antiviral response. In addition, it may also play } \\
\text { a role in other cellular processes such as apoptosis, } \\
\text { cell growth, differentiation, and gene regulation. }\end{array}$ \\
\hline SERPING1 & 3.5 & $3.3 \times 10^{-13}$ & $\begin{array}{c}\begin{array}{c}\text { Plasma protease C1 } \\
\text { inhibitor }\end{array} \\
\text { (PTHR11461:SF159) } \\
\end{array}$ & $\begin{array}{l}\text { Activation of the } \mathrm{C} 1 \text { complex is under control of the } \\
\qquad \mathrm{C} 1 \text { inhibitor. }\end{array}$ \\
\hline ENSECAG00000031838 & 3.5 & $7.1 \times 10^{-4}$ & Unknown & No UniProtKB function listed. \\
\hline CCL8 & 3.5 & $1.0 \times 10^{-14}$ & $\begin{array}{l}\text { C-C Motif Chemokine } 8 \\
\text { (PTHR12015:SF168) }\end{array}$ & $\begin{array}{l}\text { Chemotactic factor that attracts monocytes, } \\
\text { lymphocytes, basophils, and eosinophils. }\end{array}$ \\
\hline OASL & 3.4 & $6.1 \times 10^{-89}$ & $\begin{array}{l}2^{\prime}-5^{\prime} \text {-oligoadenylate } \\
\text { synthase-like protein } \\
\text { (PTHR11258:SF16) }\end{array}$ & $\begin{array}{c}\text { Does not have } 2^{\prime}-5^{\prime} \text {-OAS activity but can bind } \\
\text { double-stranded RNA. }\end{array}$ \\
\hline MYO1D & 3.4 & $5.1 \times 10^{-6}$ & $\begin{array}{c}\text { Unconventional } \\
\text { myosin-ID } \\
\text { (PTHR13140:SF417) }\end{array}$ & $\begin{array}{l}\text { Unconventional myosin that functions as } \\
\text { an actin-based motor protein with ATPase activity. }\end{array}$ \\
\hline IFIH1 & 3.3 & $2.2 \times 10^{-56}$ & $\begin{array}{l}\text { Interferon-induced } \\
\text { helicase } C \\
\text { domain-containing } \\
\text { protein } 1 \\
\text { (PTHR14074:SF14) }\end{array}$ & $\begin{array}{l}\text { Innate immune receptor which acts as } \\
\text { a cytoplasmic sensor of viral nucleic acids and } \\
\text { plays a major role in sensing viral infection and in } \\
\text { the activation of a cascade of antiviral responses } \\
\text { including the induction of type I interferons and } \\
\text { proinflammatory cytokines. }\end{array}$ \\
\hline
\end{tabular}

\begin{tabular}{cccc} 
ENSECAG00000035315 3.2 & $5.9 \times 10^{-5}$ & $\begin{array}{c}\text { immunoglobulin-like } \\
\text { receptor subfamily B } \\
\text { member 4 } \\
\text { (PTHR11738:SF174) }\end{array}$ \\
OAS3 & 3.2 & $1.2 \times 10^{-69}$ & $\begin{array}{c}2^{\prime}-5^{\prime} \text {-oligoadenylate } \\
\text { synthase 3 } \\
\text { (PTHR11258:SF4) }\end{array}$ \\
\hline
\end{tabular}

$\begin{array}{llll}\text { MPZ } & 3.1 & 1.6 \times 10^{-3} & \begin{array}{c}\text { Myelin protein P0 } \\ \text { (PTHR13869:SF7) }\end{array}\end{array}$

IFI6 $3.1 \quad 1.8 \times 10^{-70}$

Myelin protein $\mathrm{P} 0$ (PTHR13869:SF7)
Interferon alpha-inducible protein 6 (PTHR16932:SF25)
Interferon-induced, dsRNA-activated antiviral enzyme which plays a critical role in cellular innate antiviral response. In addition, it may also play a role in other cellular processes such as apoptosis, cell growth, differentiation. and gene regulation.

Is an adhesion molecule necessary for normal myelination in the peripheral nervous system. It mediates adhesion between adjacent myelin wraps and ultimately drives myelin compaction

Plays a role in apoptosis, negatively regulating the intrinsic apoptotic signaling pathway and

TNFSF10-induced apoptosis. However, it has also been shown to have a pro-apoptotic activity. Has antiviral activity towards hepatitis $\mathrm{C}$ virus (HCV) by inhibiting the epidermal growth factor receptor

(EGFR) signaling pathway, whose activation is required for entry of the virus into cells.

Key transcriptional regulator of type I interferon (IFN)-dependent immune responses and plays a critical role in the innate immune response against DNA and RNA viruses. factor 7 (PTHR11949:SF2)

\begin{tabular}{ccccc}
\hline ENSECAG00000012132 & 3.1 & $2.0 \times 10^{-55}$ & $\begin{array}{c}2^{\prime}-5^{\prime} \text {-oligoadenylate } \\
\text { synthase-like protein 2 } \\
\text { (PTHR11258:SF7) }\end{array}$ & No UniProtKB function listed. \\
\hline ENSECAG00000032818 & 3.1 & $8.9 \times 10^{-49}$ & $\begin{array}{c}\text { Interferon-induced protein } \\
\text { with tetratricopeptide } \\
\text { repeats 5 } \\
\text { (PTHR10271:SF28) }\end{array}$ & No UniProtKB function listed. \\
\hline RF01955 & 3.0 & $1.5 \times 10^{-2}$ & Unknown & No UniProtKB function listed. \\
\hline ENSECAG00000017970 & 3.0 & $1.3 \times 10^{-4}$ & $\begin{array}{c}\text { Solute carrier family 23 } \\
\text { member 4 } \\
\text { (PTHR11119:SF22) }\end{array}$ & NotKB function listed. \\
\hline
\end{tabular}


Table A1. Cont.

\begin{tabular}{|c|c|c|c|c|}
\hline Symbol & $\begin{array}{l}\text { Log2 Fold } \\
\text { Change }\end{array}$ & Padj & $\begin{array}{c}\text { PANTHER } \\
\text { Family/Subfamily }\end{array}$ & Function-UniProtKB (Homo sapiens Ortholog) \\
\hline TGM2 & 3.0 & $2.6 \times 10^{-18}$ & $\begin{array}{l}\text { Protein-glutamine gamma- } \\
\text { glutamyltransferase } 2 \\
\text { (PTHR11590:SF6) }\end{array}$ & $\begin{array}{l}\text { Catalyzes the cross-linking of proteins, such as } \\
\text { WDR54, and the conjugation of polyamines } \\
\text { to proteins. }\end{array}$ \\
\hline TRIM22 & 3.0 & $2.0 \times 10^{-139}$ & $\begin{array}{l}\text { E3 ubiquitin-protein ligase } \\
\text { TRIM22 } \\
\text { (PTHR24103:SF650) }\end{array}$ & $\begin{array}{l}\text { Interferon-induced antiviral protein involved in cell } \\
\text { innate immunity. The antiviral activity could in } \\
\text { part be mediated by TRIM22-dependent } \\
\text { ubiquitination of viral proteins. }\end{array}$ \\
\hline OAS2 & 3.0 & $6.5 \times 10^{-66}$ & $\begin{array}{l}2^{\prime}-5^{\prime} \text {-oligoadenylate } \\
\text { synthase } 2 \\
\text { (PTHR11258:SF3) }\end{array}$ & $\begin{array}{l}\text { Interferon-induced, dsRNA-activated antiviral } \\
\text { enzyme which plays a critical role in cellular innate } \\
\text { antiviral response. }\end{array}$ \\
\hline IFIT5 & 3.0 & $7.4 \times 10^{-9}$ & $\begin{array}{l}\text { Interferon-induced protein } \\
\text { with tetratricopeptide } \\
\text { repeats } 5 \\
\text { (PTHR10271:SF28) }\end{array}$ & $\begin{array}{c}\text { Interferon-induced RNA-binding protein involved } \\
\text { in the human innate immune response. Has a broad } \\
\text { and adaptable RNA structure recognition } \\
\text { important for RNA recognition specificity in } \\
\text { antiviral defense. }\end{array}$ \\
\hline SLC1A3 & 3.0 & $8.3 \times 10^{-6}$ & $\begin{array}{l}\text { Excitatory amino acid } \\
\text { transporter } 1 \\
\text { (PTHR11958:SF24) }\end{array}$ & $\begin{array}{l}\text { Sodium-dependent, high-affinity amino acid } \\
\text { transporter that mediates the uptake of L-glutamate } \\
\text { and also L-aspartate and D-aspartate. }\end{array}$ \\
\hline \multicolumn{5}{|c|}{ Downregulated genes } \\
\hline FAM71A & -4.6 & $2.4 \times 10^{-8}$ & $\begin{array}{l}\text { Protein FAM71A } \\
\text { (PTHR22574:SF15) }\end{array}$ & No UniProtKB function listed. \\
\hline FN1 & -4.0 & $6.3 \times 10^{-19}$ & Unknown & $\begin{array}{l}\text { Fibronectins bind cell surfaces and various } \\
\text { compounds including collagen, fibrin, heparin, } \\
\text { DNA, and actin. Fibronectins are involved in cell } \\
\text { adhesion, cell motility, opsonization, wound } \\
\text { healing, and maintenance of cell shape. }\end{array}$ \\
\hline DEFB1 & -3.3 & $1.7 \times 10^{-4}$ & $\begin{array}{c}\text { Beta-defensin } 1 \\
\text { (PTHR21388:SF9) }\end{array}$ & Has bactericidal activity. \\
\hline
\end{tabular}

Table A2. Mapping summary statistics for miRNA. Total reads after sequencing and the number and percent that uniquely mapped to the combined genome consisting of horse (EquCab3.0), EHV-1 (NCBI RefSeq NC_001491.2), EHV-2 (NCBI RefSeq NC_001650.2), EHV-4 (NCBI RefSeq NC_001844.1), and EHV-5 (NCBI RefSeq NC_026421.1) genomes are shown for each sample.

\begin{tabular}{|c|c|c|c|}
\hline Scheme & Total Reads & Mapped Reads (Number of Reads) & Mapped Reads (\%) \\
\hline H1_PRE & $20,352,241$ & $11,692,423$ & 57.5 \\
\hline H1_POST & $23,676,872$ & $13,834,897$ & 58.4 \\
\hline H2_PRE & $20,994,711$ & $10,117,799$ & 48.2 \\
\hline H2_POST & $20,255,481$ & $9,999,105$ & 49.4 \\
\hline H3_PRE & $20,651,994$ & $10,458,273$ & 50.6 \\
\hline H3_POST & $19,113,616$ & $9,805,906$ & 51.3 \\
\hline H5_PRE & $20,352,426$ & $9,223,249$ & 45.3 \\
\hline H5_POST & $18,477,943$ & $9,073,071$ & 49.1 \\
\hline H6_PRE & $14,388,881$ & $6,751,730$ & 46.9 \\
\hline H6_POST & $12,035,002$ & $6,261,094$ & 52.0 \\
\hline H7_PRE & $17,643,353$ & $8,970,565$ & 50.8 \\
\hline H7_POST & $13,916,919$ & $6,010,956$ & 43.2 \\
\hline H9_PRE & $13,712,739$ & $6,613,096$ & 48.2 \\
\hline H9_POST & $18,748,418$ & $8,506,104$ & 45.4 \\
\hline Average & $18,165,757$ & $9,094,162$ & 49.7 \\
\hline
\end{tabular}




\section{References}

1. Pellett, P.; Roizman, B. Chapter 59. Herpesviridae. In Fields Virology; Knipe, D., Howley, P., Cohen, J., Griffin, D., Lamb, R., Martin, M., Racaniello, V., Roizman, B., Eds.; Lippincott, Williams \& Wilkins: Philadelphia, PA, USA, 2013 ; pp. $1803-1822$.

2. Oladunni, F.S.; Horohov, D.W.; Chambers, T.M. EHV-1: A Constant Threat to the Horse Industry. Front. Microbiol. 2019, 10, 2668. [CrossRef] [PubMed]

3. Pusterla, N.; Mapes, S.; Wilson, W.D. Prevalence of equine herpesvirus type 1 in trigeminal ganglia and submandibular lymph nodes of equids examined postmortem. Vet. Rec. 2010, 167, 376-378. [CrossRef] [PubMed]

4. Allen, G.P. Antemortem detection of latent infection with neuropathogenic strains of equine herpesvirus-1 in horses. Am. J. Vet. Res. 2006, 67, 1401-1405. [CrossRef] [PubMed]

5. $\quad$ Allen, G.P.; Bolin, D.C.; Bryant, U.; Carter, C.N.; Giles, R.C.; Harrison, L.R.; Hong, C.B.; Jackson, C.B.; Poonacha, K.; Wharton, R.; et al. Prevalence of latent, neuropathogenic equine herpesvirus-1 in the Thoroughbred broodmare population of central Kentucky. Equine Vet. J. 2008, 40, 105-110. [CrossRef]

6. Slater, J.D.; Borchers, K.; Thackray, A.M.; Field, H.J. The trigeminal ganglion is a location for equine herpesvirus 1 latency and reactivation in the horse. J. Gen. Virol. 1994, 75, 2007-2016. [CrossRef]

7. Giessler, K.S.; Samoilowa, S.; Soboll Hussey, G.; Kiupel, M.; Matiasek, K.; Sledge, D.J.; Liesche, F.; Schlegel, J.; Fux, R.; Goehring, L.S. Viral load and cell tropism during early latent Equid Herpesvirus 1 infection differ over time in lymphoid and neural tissue samples from experimentally infected horses. Front. Vet. Sci. 2020, 7. [CrossRef]

8. Marenzoni, M.L.; Stefanetti, V.; Danzetta, M.L.; Timoney, P.J. Gammaherpesvirus infections in equids: A review. Vet. Med. 2015, 6, 91-101. [CrossRef]

9. Lunn, D.P.; Davis-Poynter, N.; Flaminio, M.J.B.F.; Horohov, D.W.; Osterrieder, K.; Pusterla, N.; Townsend, H.G.G. Equine herpesvirus-1 consensus statement. J. Vet. Intern. Med. 2009, 23, 450-461. [CrossRef]

10. van Maanen, C. Equine herpesvirus 1 and 4 infections: An update. Vet. Q. 2002, 24, 58-78. [CrossRef]

11. Gryspeerdt, A.C.; Vandekerckhove, A.P.; Garré, B.; Barbé, F.; Van de Walle, G.R.; Nauwynck, H.J. Differences in replication kinetics and cell tropism between neurovirulent and non-neurovirulent EHV1 strains during the acute phase of infection in horses. Vet. Microbiol. 2010, 142, 242-253. [CrossRef]

12. Wilsterman, S.; Soboll-Hussey, G.; Lunn, D.P.; Ashton, L.V.; Callan, R.J.; Hussey, S.B.; Rao, S.; Goehring, L.S. Equine herpesvirus-1 infected peripheral blood mononuclear cell subpopulations during viremia. Vet. Microbiol. 2011, 149, 40-47. [CrossRef] [PubMed]

13. Goodman, L.B.; Loregian, A.; Perkins, G.A.; Nugent, J.; Buckles, E.L.; Mercorelli, B.; Kydd, J.H.; Palù, G.; Smith, K.C.; Osterrieder, N.; et al. A point mutation in a herpesvirus polymerase determines neuropathogenicity. PLoS Pathog. 2007, 3, e160. [CrossRef] [PubMed]

14. Scott, J.C.; Dutta, S.K.; Myrup, A.C. In vivo harboring of equine herpesvirus-1 in leukocyte populations and subpopulations and their quantitation from experimentally infected ponies. Am. J. Vet. Res. 1983, 44, 1344-1348. [PubMed]

15. van Der Meulen, K.M.; Nauwynck, H.J.; Buddaert, W.; Pensaert, M.B. Replication of equine herpesvirus type 1 in freshly isolated equine peripheral blood mononuclear cells and changes in susceptibility following mitogen stimulation. J. Gen. Virol. 2000, 81, 21-25. [CrossRef] [PubMed]

16. Laval, K.; Favoreel, H.W.; Nauwynck, H.J. Equine herpesvirus type 1 replication is delayed in CD172a+ monocytic cells and controlled by histone deacetylases. J. Gen. Virol. 2015, 96, 118-130. [CrossRef]

17. Laval, K.; Favoreel, H.W.; Poelaert, K.C.K.; Van Cleemput, J.; Nauwynck, H.J. Equine herpesvirus type 1 enhances viral replication in CD172a+ monocytic cells upon adhesion to endothelial cells. J. Virol. 2015, 89, 10912-10923. [CrossRef]

18. Poelaert, K.C.K.; Van Cleemput, J.; Laval, K.; Favoreel, H.W.; Couck, L.; Van den Broeck, W.; Azab, W.; Nauwynck, H.J. Equine herpesvirus 1 bridles T-lymphocytes to reach its target organs. J. Virol. 2019. [CrossRef]

19. Allen, G.P. Risk factors for development of neurologic disease after experimental exposure to equine herpesvirus- 1 in horses. Am. J. Vet. Res. 2008, 69, 1595-1600. [CrossRef]

20. Soboll Hussey, G.; Hussey, S.B.; Wagner, B.; Horohov, D.W.; Van de Walle, G.R.; Osterrieder, N.; Goehring, L.S.; Rao, S.; Lunn, D.P. Evaluation of immune responses following infection of ponies with an EHV-1 ORF1/2 deletion mutant. Vet. Res. 2011, 42. [CrossRef]

21. Holz, C.L.; Nelli, R.K.; Eilidh Wilson, M.; Zarski, L.M.; Azab, W.; Baumgardner, R.; Osterrieder, N.; Pease, A.; Zhang, L.; Hession, S.; et al. Viral genes and cellular markers associated with neurological complications during herpesvirus infections. J. Gen. Virol. 2017, 98. [CrossRef]

22. Wimer, C.L.; Damiani, A.; Osterrieder, N.; Wagner, B. Equine herpesvirus type-1 modulates CCL2, CCL3, CCL5, CXCL9, and CXCL10 chemokine expression. Vet. Immunol. Immunopathol. 2011, 140, 266-274. [CrossRef]

23. Wagner, B.; Wimer, C.; Freer, H.; Osterrieder, N.; Erb, H.N. Infection of peripheral blood mononuclear cells with neuropathogenic equine herpesvirus type- 1 strain $\mathrm{Ab} 4$ reveals intact interferon-alpha induction and induces suppression of anti-inflammatory interleukin-10 responses in comparison to other viral strains. Vet. Immunol. Immunopathol. 2011, 143, 116-124. [CrossRef]

24. Shukla, G.C.; Singh, J.; Barik, S. MicroRNAs: Processing, maturation, target recognition and regulatory functions. Mol. Cell. Pharmacol. 2011, 3, 83-92. [PubMed]

25. Zheng, S.; Li, Y.; Zhang, Y.; Li, X.; Tang, H. MiR-101 regulates HSV-1 replication by targeting ATP5B. Antivir. Res. 2011, 89, 219-226. [CrossRef] [PubMed] 
26. Boss, I.W.; Renne, R. Viral miRNAs and immune evasion. Biochim. Biophys. Acta 2011, 1809, 708-714. [CrossRef] [PubMed]

27. Zarski, L.M.; Seong, K.K.; Lee, Y.; Holz, C.L.; Nelli, R.K.; Weber, P.S.D.; Soboll Hussey, G. Administration of recombinant adenovirus expressing inhibitory IR2 protein for control of equine herpesvirus 1 infection and disease. 2020. prepare.

28. Newman, A.M.; Steen, C.B.; Liu, C.L.; Gentles, A.J.; Chaudhuri, A.A.; Scherer, F.; Khodadoust, M.S.; Esfahani, M.S.; Luca, B.A.; Steiner, D.; et al. Determining cell type abundance and expression from bulk tissues with digital cytometry. Nat. Biotechnol. 2019, 37, 773-782. [CrossRef]

29. Matsumura, T.; Kondo, T.; Sugita, S.; Damiani, A.M.; O'Callaghan, D.J.; Imagawa, H. An Equine Herpesvirus Type 1 Recombinant with a Deletion in the gE and gI Genes Is Avirulent in Young Horses. Virology 1998, 242, 68-79. [CrossRef] [PubMed]

30. Shakya, A.K.; O'Callaghan, D.J.; Kim, S.K. Comparative Genomic Sequencing and Pathogenic Properties of Equine Herpesvirus 1 KyA and RacL11. Front. Vet. Sci. 2017, 4, 211. [CrossRef] [PubMed]

31. Said, A.; Osterrieder, N. Equine herpesvirus type 1 (EHV-1) open reading frame 59 encodes an early protein that is localized to the cytosol and required for efficient virus growth. Virology 2014, 449, 263-269. [CrossRef]

32. Lischka, P.; Sorg, G.; Kann, M.; Winkler, M.; Stamminger, T. A nonconventional nuclear localization signal within the UL84 protein of human cytomegalovirus mediates nuclear import via the importin alpha/beta pathway. J. Virol. 2003, 77, 3734-3748. [CrossRef] [PubMed]

33. Huang, R.; Hu, Z.; Cao, Y.; Li, H.; Zhang, H.; Su, W.; Xu, Y.; Liang, L.; Melgiri, N.D.; Jiang, L. MiR-652-3p inhibition enhances endothelial repair and reduces atherosclerosis by promoting Cyclin D2 expression. EBioMedicine 2019, 40, 685-694. [CrossRef] [PubMed]

34. Poudyal, D.; Herman, A.; Adelsberger, J.W.; Yang, J.; Hu, X.; Chen, Q.; Bosche, M.; Sherman, B.T.; Imamichi, T. A novel microRNA, hsa-miR-6852 differentially regulated by Interleukin-27 induces necrosis in cervical cancer cells by downregulating the FoxM1 expression. Sci. Rep. 2018, 8, 900. [CrossRef] [PubMed]

35. Brosnahan, M.M.; Al Abri, M.A.; Brooks, S.A.; Antczak, D.F.; Osterrieder, N. Genome-wide association study of equine herpesvirus type 1-induced myeloencephalopathy identifies a significant single nucleotide polymorphism in a platelet-related gene. Vet. J. 2019, 245, 49-54. [CrossRef]

36. Rubinstein, E. The complexity of tetraspanins. Biochem. Soc. Trans. 2011, 39, 501-505. [CrossRef]

37. Haining, E.J.; Matthews, A.L.; Noy, P.J.; Romanska, H.M.; Harris, H.J.; Pike, J.; Morowski, M.; Gavin, R.L.; Yang, J.; Milhiet, P.-E.; et al. Tetraspanin Tspan9 regulates platelet collagen receptor GPVI lateral diffusion and activation. Platelets 2017, $28,629-642$. [CrossRef]

38. Mossman, K.L.; Ashkar, A.A. Herpesviruses and the innate immune response. Viral Immunol. 2005, 18, 267-281. [CrossRef]

39. Ivashkiv, L.B.; Donlin, L.T. Regulation of type I interferon responses. Nat. Rev. Immunol. 2014, 14, 36-49. [CrossRef]

40. Kumari, P.; Narayanan, S.; Kumar, H. Herpesviruses: Interfering innate immunity by targeting viral sensing and interferon pathways. Rev. Med. Virol. 2015, 25, 187-201. [CrossRef]

41. Dupuis, S.; Jouanguy, E.; Al-Hajjar, S.; Fieschi, C.; Al-Mohsen, I.Z.; Al-Jumaah, S.; Yang, K.; Chapgier, A.; Eidenschenk, C.; Eid, P.; et al. Impaired response to interferon- $\alpha / \beta$ and lethal viral disease in human STAT1 deficiency. Nat. Genet. 2003, 33, 388-391. [CrossRef]

42. Bin, L.; Edwards, M.G.; Heiser, R.; Streib, J.; Richers, B.; Leung, D.Y.M. Identification of Novel Gene Signatures in Atopic Dermatitis Complicated by Eczema Herpeticum. J. Allergy Clin. Immunol. 2014, 133, AB193. [CrossRef]

43. Soboll Hussey, G.; Ashton, L.V.; Quintana, A.M.; Lunn, D.P.; Goehring, L.S.; Annis, K.; Landolt, G. Innate immune responses of airway epithelial cells to infection with equine herpesvirus-1. Vet. Microbiol. 2014, 170, 28-38. [CrossRef] [PubMed]

44. Soboll Hussey, G.; Ashton, L.V.; Quintana, A.M.; Van de Walle, G.R.; Osterrieder, N.; Lunn, D.P. Equine herpesvirus type 1 pUL56 modulates innate responses of airway epithelial cells. Virology 2014, 464-465, 76-86. [CrossRef] [PubMed]

45. Quintana, A.M.; Landolt, G.A.; Annis, K.M.; Hussey, G.S. Immunological characterization of the equine airway epithelium and of a primary equine airway epithelial cell culture model. Vet. Immunol. Immunopathol. 2011, 140, 226-236. [CrossRef]

46. Poelaert, K.C.K.; Van Cleemput, J.; Laval, K.; Favoreel, H.W.; Soboll Hussey, G.; Maes, R.K.; Nauwynck, H.J. Abortigenic but Not Neurotropic Equine Herpes Virus 1 Modulates the Interferon Antiviral Defense. Front. Cell. Infect. Microbiol. 2018,8 , 312. [CrossRef]

47. Oladunni, F.S.; Sarkar, S.; Reedy, S.; Balasuriya, U.B.R.; Horohov, D.W.; Chambers, T.M. Equid Herpesvirus 1 Targets the Sensitization and Induction Steps to Inhibit the Type I Interferon Response in Equine Endothelial Cells. J. Virol. $2019,93$. [CrossRef]

48. Sarkar, S.; Balasuriya, U.B.R.; Horohov, D.W.; Chambers, T.M. Equine herpesvirus-1 suppresses type-I interferon induction in equine endothelial cells. Vet. Immunol. Immunopathol. 2015, 167, 122-129. [CrossRef]

49. Scherer, C.A.; Magness, C.L.; Steiger, K.V.; Poitinger, N.D.; Caputo, C.M.; Miner, D.G.; Winokur, P.L.; Klinzman, D.; McKee, J.; Pilar, C.; et al. Distinct gene expression profiles in peripheral blood mononuclear cells from patients infected with vaccinia virus, yellow fever 17D virus, or upper respiratory infections. Vaccine 2007, 25, 6458-6473. [CrossRef]

50. Schmid, S.; Mordstein, M.; Kochs, G.; García-Sastre, A.; Tenoever, B.R. Transcription factor redundancy ensures induction of the antiviral state. J. Biol. Chem. 2010, 285, 42013-42022. [CrossRef]

51. Groom, J.R.; Luster, A.D. CXCR3 ligands: Redundant, collaborative and antagonistic functions. Immunol. Cell Biol. 2011, 89, 207-215. [CrossRef] 
52. Poelaert, K.C.K.; Van Cleemput, J.; Laval, K.; Xie, J.; Favoreel, H.W.; Nauwynck, H.J. Equine herpesvirus 1 infection orchestrates the expression of chemokines in equine respiratory epithelial cells. J. Gen. Virol. 2019. [CrossRef] [PubMed]

53. Johnstone, S.; Barsova, J.; Campos, I.; Frampton, A.R. Equine herpesvirus type 1 modulates inflammatory host immune response genes in equine endothelial cells. Vet. Microbiol. 2016, 192, 52-59. [CrossRef] [PubMed]

54. Proost, P.; Wuyts, A.; van Damme, J. Human monocyte chemotactic proteins-2 and -3: Structural and functional comparison with MCP-1. J. Leukoc. Biol. 1996, 59, 67-74. [CrossRef] [PubMed]

55. Sun, Y.; Iglesias, E.; Samri, A.; Kamkamidze, G.; Decoville, T.; Carcelain, G.; Autran, B. A systematic comparison of methods to measure HIV-1 specific CD8 T cells. J. Immunol. Methods 2003, 272, 23-34. [CrossRef]

56. Guidotti, L.G.; Chisari, F.V. Noncytolytic control of viral infections by the innate and adaptive immune response. Annu. Rev. Immunol. 2001, 19, 65-91. [CrossRef] [PubMed]

57. O'Neill, T.; Kydd, J.H.; Allen, G.P.; Wattrang, E.; Mumford, J.A.; Hannant, D. Determination of equid herpesvirus 1-specific, CD8+, cytotoxic T lymphocyte precursor frequencies in ponies. Vet. Immunol. Immunopathol. 1999, 70, 43-54. [CrossRef]

58. Kydd, J.H.; Wattrang, E.; Hannant, D. Pre-infection frequencies of equine herpesvirus-1 specific, cytotoxic T lymphocytes correlate with protection against abortion following experimental infection of pregnant mares. Vet. Immunol. Immunopathol. 2003, 96, 207-217. [CrossRef]

59. Paillot, R.; Ellis, S.A.; Daly, J.M.; Audonnet, J.C.; Minke, J.M.; Davis-Poynter, N.; Hannant, D.; Kydd, J.H. Characterisation of CTL and IFN- $\gamma$ synthesis in ponies following vaccination with a NYVAC-based construct coding for EHV-1 immediate early gene, followed by challenge infection. Vaccine 2006, 24, 1490-1500. [CrossRef]

60. Paillot, R.; Daly, J.M.; Luce, R.; Montesso, F.; Davis-Poynter, N.; Hannant, D.; Kydd, J.H. Frequency and phenotype of EHV-1 specific, IFN- $\gamma$ synthesising lymphocytes in ponies: The effects of age, pregnancy and infection. Dev. Comp. Immunol. 2007, 31, 202-214. [CrossRef]

61. Breathnach, C.C.; Soboll, G.; Suresh, M.; Lunn, D.P. Equine herpesvirus-1 infection induces IFN-gamma production by equine T lymphocyte subsets. Vet. Immunol. Immunopathol. 2005, 103, 207-215. [CrossRef]

62. Favoreel, H.W.; Nauwynck, H.J.; Pensaert, M.B. Immunological hiding of herpesvirus-infected cells. Arch. Virol. 2000, 145, 1269-1290. [CrossRef] [PubMed]

63. van der Meulen, K.M.; Nauwynck, H.J.; Pensaert, M.B. Absence of viral antigens on the surface of equine herpesvirus-1-infected peripheral blood mononuclear cells: A strategy to avoid complement-mediated lysis. J. Gen. Virol. 2003, 84, 93-97. [CrossRef] [PubMed]

64. Carroll, M.C. The complement system in B cell regulation. Mol. Immunol. 2004, 41, 141-146. [CrossRef] [PubMed]

65. Wagner, C.; Hänsch, G.M. Receptors for complement C3 on T-lymphocytes: Relics of evolution or functional molecules? Mol. Immunol. 2006, 43, 22-30. [CrossRef] [PubMed]

66. Wagner, C.; Ochmann, C.; Schoels, M.; Giese, T.; Stegmaier, S.; Richter, R.; Hug, F.; Hänsch, G.M. The complement receptor 1, CR1 (CD35), mediates inhibitory signals in human T-lymphocytes. Mol. Immunol. 2006, 43, 643-651. [CrossRef] [PubMed]

67. Wilson, J.G.; Tedder, T.F.; Fearon, D.T. Characterization of human T lymphocytes that express the C3b receptor. J. Immunol. 1983, $131,684-689$.

68. Werfel, T.; Kirchhoff, K.; Wittmann, M.; Begemann, G.; Kapp, A.; Heidenreich, F.; Götze, O.; Zwirner, J. Activated Human T Lymphocytes Express a Functional C3a Receptor. J. Immunol. 2000, 165, 6599-6605. [CrossRef]

69. Oikonomopoulou, K.; Ricklin, D.; Ward, P.A.; Lambris, J.D. Interactions between coagulation and complement-Their role in inflammation. Semin. Immunopathol. 2012, 34, 151-165. [CrossRef]

70. Davis, A.E., 3rd. Biological effects of C1 inhibitor. Drug News Perspect. 2004, 17, 439-446. [CrossRef]

71. Yeo, W.M.; Osterrieder, N.; Stokol, T. Equine herpesvirus type 1 infection induces procoagulant activity in equine monocytes. Vet. Res. 2013, 44, 16. [CrossRef]

72. Stokol, T.; Yeo, W.M.; Burnett, D.; DeAngelis, N.; Huang, T.; Osterrieder, N.; Catalfamo, J. Equid Herpesvirus Type 1 Activates Platelets. PLoS ONE 2015, 10, e0122640. [CrossRef] [PubMed]

73. Goehring, L.S.; Soboll Hussey, G.; Gomez Diez, M.; Benedict, K.; Maxwell, L.K.; Morley, P.S.; Sloet van Oldruitenborgh-Oosterbaan, M.M.; Lunn, D.P. Plasma D-Dimer Concentrations during Experimental EHV-1 Infection of Horses. J. Vet. Intern. Med. 2013, 27, 1535-1542. [CrossRef] [PubMed]

74. Wilson, M.E.; Holz, C.L.; Kopec, A.K.; Dau, J.J.; Luyendyk, J.P.; Soboll Hussey, G. Coagulation parameters following equine herpesvirus type 1 infection in horses. Equine Vet. J. 2019, 51, 102-107. [CrossRef] [PubMed]

75. Adams, R.L.C.; Bird, R.J. Review article: Coagulation cascade and therapeutics update: Relevance to nephrology. Part 1: Overview of coagulation, thrombophilias and history of anticoagulants. Nephrology 2009, 14, 462-470. [CrossRef] [PubMed]

76. Sang, Y.; Miller, L.C.; Blecha, F. Macrophage Polarization in Virus-Host Interactions. J. Clin. Cell. Immunol. 2015, 6, 311. [CrossRef] [PubMed]

77. Sutton, C.E.; Mielke, L.A.; Mills, K.H.G. IL-17-producing $\gamma \delta$ T cells and innate lymphoid cells. Eur. J. Immunol. 2012, 42, $2221-2231$. [CrossRef] [PubMed]

78. van der Meulen, K.; Caij, B.; Pensaert, M.; Nauwynck, H. Absence of viral envelope proteins in equine herpesvirus 1-infected blood mononuclear cells during cell-associated viremia. Vet. Microbiol. 2006, 113, 265-273. [CrossRef] 
79. Lunn, D.P.; Holmes, M.A.; Gibson, J.; Field, H.J.; Kydd, J.H.; Duffus, W.P.H. Haematological changes and equine lymphocyte subpopulation kinetics during primary infection and attempted re-infection of specific pathogen free foals with EHV-1. Equine Vet. J. 1991, 23, 35-40. [CrossRef]

80. McCulloch, J.; Williamson, S.A.; Powis, S.J.; Edington, N. The effect of EHV-1 infection upon circulating leucocyte populations in the natural equine host. Vet. Microbiol. 1993, 37, 147-161. [CrossRef]

81. Gilkerson, J.R.; Whalley, J.M.; Drummer, H.E.; Studdert, M.J.; Love, D.N. Epidemiological studies of equine herpesvirus 1 (EHV-1) in Thoroughbred foals: A review of studies conducted in the Hunter Valley of New South Wales between 1995 and 1997. Vet. Microbiol. 1999, 68, 15-25. [CrossRef]

82. Gilkerson, J.R.; Whalley, J.M.; Drummer, H.E.; Studdert, M.J.; Love, D.N. Epidemiology of EHV-1 and EHV-4 in the mare and foal populations on a Hunter Valley stud farm: Are mares the source of EHV-1 for unweaned foals. Vet. Microbiol. 1999, 68, 27-34. [CrossRef]

83. Foote, C.E.; Love, D.N.; Gilkerson, J.R.; Whaley, J.M. Detection of EHV-1 and EHV-4 DNA in unweaned Thoroughbred foals from vaccinated mares on a large stud farm. Equine Vet. J. 2010, 36, 341-345. [CrossRef] [PubMed]

84. Mumford, J.A.; Rossdale, P.D.; Jessett, D.M.; Gann, S.J.; Ousey, J. Serological and virological investigations of an equid herpesvirus 1 (EHV-1) abortion storm on a stud farm in 1985. J. Reprod. Fertil. Suppl. 1987, 35, 509-518. [PubMed]

85. Cox, E.; Reddy, S.; Iofin, I.; Cohen, J.I. Varicella-Zoster Virus ORF57, Unlike Its Pseudorabies Virus UL3.5 Homolog, Is Dispensable for Viral Replication in Cell Culture. Virology 1998, 250, 205-209. [CrossRef] [PubMed]

86. Dean, H.J.; Cheung, A.K. A $3^{\prime}$ coterminal gene cluster in pseudorabies virus contains herpes simplex virus UL1, UL2, and UL3 gene homologs and a unique UL3.5 open reading frame. J. Virol. 1993, 67, 5955-5961. [CrossRef]

87. Chaudhuri, V.; Sommer, M.; Rajamani, J.; Zerboni, L.; Arvin, A.M. Functions of Varicella-Zoster Virus ORF23 Capsid Protein in Viral Replication and the Pathogenesis of Skin Infection. J. Virol. 2008, 82, 10231-10246. [CrossRef]

88. Sun, Y.; Brown, S.M. The Open Reading Frames 1, 2, 71, and 75 Are Nonessential for the Replication of Equine Herpesvirus Type 1 in Vitro. Virology 1994, 199, 448-452. [CrossRef]

89. Hussey, G.S.; Goehring, L.S.; Lunn, D.P.; Hussey, S.B.; Huang, T.; Osterrieder, N.; Powell, C.; Hand, J.; Holz, C.; Slater, J. Experimental infection with equine herpesvirus type 1 (EHV-1) induces chorioretinal lesions. Vet. Res. 2013, 44, 118. [CrossRef]

90. Drummer, H.E.; Reubel, G.H.; Studdert, M.J. Equine gammaherpesvirus 2 (EHV2) is latent in B lymphocytes. Arch. Virol. 1996, 141, 495-504. [CrossRef]

91. Mekuria, Z.H.; El-Hage, C.; Ficorilli, N.P.; Washington, E.A.; Gilkerson, J.R.; Hartley, C.A. Mapping B lymphocytes as major reservoirs of naturally occurring latent equine herpesvirus 5 infection. J. Gen. Virol. 2017, 98, 461-470. [CrossRef]

92. Wang, L.; Raidal, S.L.; Pizzirani, A.; Wilcox, G.E. Detection of respiratory herpesviruses in foals and adult horses determined by nested multiplex PCR. Vet. Microbiol. 2007, 121, 18-28. [CrossRef] [PubMed]

93. Zarski, L.M.; High, E.A.; Nelli, R.K.; Bolin, S.R.; Williams, K.J.; Hussey, G. Development and application of a quantitative PCR assay to study equine herpesvirus 5 invasion and replication in equine tissues in vitro and in vivo. J. Virol. Methods 2017, 248. [CrossRef] [PubMed]

94. Miglio, A.; Morelli, C.; Gialletti, R.; Lauteri, E.; Sforna, M.; Marenzoni, M.L.; Antognoni, M.T. Clinical and immunophenotypic findings in 4 forms of equine lymphoma. Can. Vet. J. 2019, 60, 33-40. [PubMed]

95. Miglio, A.; Antognoni, M.T.; Morelli, C.; Gialletti, R. Third Eyelid T-cell-Rich Large B-cell Lymphoma Positive to EHV-5 in a Mare-A Case Report. J. Equine Vet. Sci. 2018, 70, 52-56. [CrossRef]

96. Bell, S.A.; Balasuriya, U.B.R.; Gardner, I.A.; Barry, P.A.; Wilson, W.D.; Ferraro, G.L.; MacLachlan, N.J. Temporal detection of equine herpesvirus infections of a cohort of mares and their foals. Vet. Microbiol. 2006, 116, 249-257. [CrossRef]

97. Akkutay, A.Z.; Osterrieder, N.; Damiani, A.; Tischer, B.K.; Borchers, K.; Alkan, F. Prevalence of equine gammaherpesviruses on breeding farms in Turkey and development of a TaqMan MGB real-time PCR to detect equine herpesvirus 5 (EHV-5). Arch. Virol. 2014, 159, 2989-2995. [CrossRef]

98. Anders, S.; Pyl, P.T.; Huber, W. HTSeq-A Python framework to work with high-throughput sequencing data. Bioinformatics 2014, 31, 166-169. [CrossRef]

99. Li, H.; Handsaker, B.; Wysoker, A.; Fennell, T.; Ruan, J.; Homer, N.; Marth, G.; Abecasis, G.; Durbin, R.; Subgroup, 1000 Genome Project Data Processing. The Sequence Alignment/Map format and SAMtools. Bioinformatics 2009, 25, 2078-2079. [CrossRef]

100. Pertea, M.; Kim, D.; Pertea, G.M.; Leek, J.T.; Salzberg, S.L. Transcript-level expression analysis of RNA-seq experiments with HISAT, StringTie and Ballgown. Nat. Protoc. 2016, 11, 1650. [CrossRef]

101. Andrews, S. FastQC: A Quality Control Tool for High Throughput Sequence Data. Available online: http://www.bioinformatics. babraham.ac.uk/projects/fastqc/ (accessed on 2 January 2020).

102. Martin, M. Cutadapt removes adapter sequences from high-throughput sequencing reads. EMBnet. J. 2011, 17, 10-12. [CrossRef]

103. Friedländer, M.R.; Mackowiak, S.D.; Li, N.; Chen, W.; Rajewsky, N. miRDeep2 accurately identifies known and hundreds of novel microRNA genes in seven animal clades. Nucleic Acids Res. 2011, 40, 37-52. [CrossRef] [PubMed]

104. Griffiths-Jones, S.; Saini, H.K.; van Dongen, S.; Enright, A.J. miRBase: Tools for microRNA genomics. Nucleic Acids Res. 2007, 36, D154-D158. [CrossRef]

105. Love, M.I.; Huber, W.; Anders, S. Moderated estimation of fold change and dispersion for RNA-seq data with DESeq2. Genome Biol. 2014, 15, 550. [CrossRef] [PubMed] 
106. Yu, G.; Wang, L.-G.; Han, Y.; He, Q.-Y. clusterProfiler: An R Package for Comparing Biological Themes Among Gene Clusters. Omics J. Integr. Biol. 2012, 16, 284-287. [CrossRef]

107. Carlson, M. org.Hs.eg.db: Genome Wide Annotation for Human. 2019. Available online: https://bioconductor.org/packages/ release/data/annotation/html/org.Hs.eg.db.html (accessed on 20 December 2020).

108. Supek, F.; Bošnjak, M.; Škunca, N.; Šmuc, T. REVIGO Summarizes and Visualizes Long Lists of Gene Ontology Terms. PLoS ONE 2011, 6, e21800. [CrossRef] [PubMed]

109. Agarwal, V.; Bell, G.W.; Nam, J.-W.; Bartel, D.P. Predicting effective microRNA target sites in mammalian mRNAs. Elife 2015, 4, e05005. [CrossRef] [PubMed]

110. Robinson, J.T.; Thorvaldsdóttir, H.; Winckler, W.; Guttman, M.; Lander, E.S.; Getz, G.; Mesirov, J.P. Integrative genomics viewer. Nat. Biotechnol. 2011, 29, 24-26. [CrossRef]

111. Robinson, M.D.; McCarthy, D.J.; Smyth, G.K. edgeR: A Bioconductor package for differential expression analysis of digital gene expression data. Bioinformatics 2009, 26, 139-140. [CrossRef] 